\title{
Review of available data for a South African Inventory of Inland Aquatic Ecosystems (SAIIAE)
}

\author{
Heidi van Deventer ${ }^{1,2 *}$, Lindie Smith-Adao', Chantel Petersen', Namhla Mbona ${ }^{3}$, \\ Andrew Skowno ${ }^{3}$ and Jeanne $\mathrm{L} \mathrm{Nel}^{4,5}$ \\ ${ }^{1}$ Council for Scientific and Industrial Research (CSIR), PO Box 395, Pretoria 0001, South Africa \\ ${ }^{2}$ School of Geography, Archaeology and Environmental Studies, University of the Witwatersrand, Private Bag 3, WITS 2050, South Africa \\ ${ }^{3}$ South African National Biodiversity Institute, Private Bag x101, Pretoria, 0001, South Africa \\ ${ }^{4}$ Institute for Environmental Studies, Faculty of Science, Vrije Universiteit Amsterdam, De Boelelaan 1087, 1081 HV Amsterdam, The Netherlands \\ ${ }^{5}$ Sustainability Research Unit, Nelson Mandela University, Private Bag X6531, George 6530, South Africa
}

\begin{abstract}
The National Biodiversity Assessment of 2011 found freshwater ecosystems to be highly threatened and poorly protected. However, a number of studies have shown that the National Wetland Map (NWM) Version 4 represents less than 54\% of wetlands mapped at a fine scale. A more comprehensive South African Inventory of Inland Aquatic Ecosystems (SAIIAE) would greatly improve the assessment of wetland ecosystem types and their condition and conservation status, and is crucial for monitoring trends to inform decision making and planning. In preparation for the third National Biodiversity Assessment of 2018, a review was undertaken to identify possible data sources that could contribute to the SAIIAE. The objectives of the study were to (i) assess which type of information is available for developing a SAIIAE; and (ii) list and understand the availability of fine-scale wetland data for updating the NWM. A variety of data related to species occurrence and distribution, extent and type of inland wetlands and rivers, as well as datasets which describe regional settings of inland aquatic ecosystems, were found across a number of institutions. Fine-scale spatial data amounted to more than double the extent of inland wetlands mapped by remote sensing at a country-wide scale. Nearly 5 million ha of fine-scale data were collected from a diverse number of institutions, with the majority (73\%) of these data mapped by Government (3 681503 ha or 3\% of South Africa). It is estimated that $<8 \%$ of the sub-quaternary catchments of South Africa had complete wetland data sets, primarily in the Gauteng, Mpumalanga and Western Cape Provinces. Accuracy assessment reports and confidence ratings were however not consistently available for the wetland datasets. Inland wetlands in the majority of South Africa (84\%) therefore remain poorly represented. We recommend future steps to improve the SAIIAE, including improving the representation of inland wetland ecosystem types and focusing on accuracy assessment.
\end{abstract}

Keywords: wetland inventory, National Wetland Map, river/wetland ecosystem types, inland aquatic ecosystems, National Biodiversity Assessment

\section{INTRODUCTION}

South Africa is considered one of 17 megadiverse countries in the world (Mittermeier et al., 1997). The diversity of inland aquatic ecosystem types in South Africa, formerly referred to as 'freshwater ecosystems' are recognised in a framework for wetland types, titled the Classification System for Wetlands and other Aquatic Ecosystems in South Africa (Ollis et al., 2013; SANBI, 2009), which was implemented through the National Wetland Map (NWM) Version 4 (Nel et al., 2011). The biodiversity of river ecosystems of South Africa was first assessed in the National Spatial Biodiversity Assessment in 2004, while wetlands were included with the river ecosystems in the National Biodiversity Assessments (NBA) of 2011 (Driver et al., 2005; Nel et al., 2011; Driver et al., 2012). Inland aquatic ecosystems support a high diversity of aquatic species which provide direct benefits in the form of water, food, building material and medicine, as well as indirect benefits such as water filtration and flood control (Darwall et al., 2009; Kotze et al., 2009). Inland aquatic ecosystems in South Africa, as in many other countries, are however under threat from a

\footnotetext{
To whom all correspondence should be addressed.

空 +27 12841 2507; Fax: +27 12841 3909;

e-mail: HvDeventer@csir.co.za

Received 25 August 2017; accepted in revised form 12 March 2018
}

number of pressures, including an increased demand for water, urbanisation, changes in climatic conditions, and invasive species. The NBA of 2011 (NBA 2011) found inland aquatic ecosystems to be highly threatened and poorly protected, and therefore the accurate inventorying of inland aquatic ecosystems in South Africa is crucial for monitoring trends, and informing decision making and planning (Nel et al., 2011).

The inventory of South African inland aquatic ecosystems has thus far focused only on the extent and types of rivers and wetlands, which is often referred to as a National Wetland Map. A wetland inventory is defined by Finlayson et al. (1999 p. 718) as 'the collection and/or collation of core information for wetland management, including the provision of an information base for specific assessment and monitoring activities'. Whereas a wetland directory is considered to be a list of coordinates of wetland location and possibly type, an inventory would consist of core datasets which would support the typing of ecosystems, as well as additional information related to landuse, impacts, conservation and management (Finlayson et al., 1999). A wetland inventory therefore encompasses more information than the extent and type of wetland ecosystems, which are generally included in a wetland map.

The first directories of inland wetlands of South Africa date to the early 1970s and of rivers to the 1980s (Noble and Hemens, 1978; O'Keeffe, 1986). A more comprehensive inventory of priority wetlands was undertaken for the 
KwaZulu-Natal Province, mapping as far as possible the historical extent and pressures on these systems (Begg, 1988). The study showed that $58 \%$ of wetlands in the Mfolozi catchment had been altered or lost, reducing the extent of wetlands from $5 \%$ to $2.1 \%$ of the surface area of the catchment. Subsequent to these initial efforts, the Department of Environmental Affairs and Tourism compiled a directory of wetland types in 1998 (Cowan and Van Riet, 1998). Efforts to update these initial wetland directories extended to mapping the spatial extent of rivers and inland wetlands at a national scale for the NBAs, and formalising the framework for the Classification System. South Africa defines an aquatic ecosystem as 'an ecosystem that is permanently or periodically inundated by flowing or standing water, or which has soils that are permanently or periodically saturated within $0.5 \mathrm{~m}$ of the soil surface' (Ollis et al., 2013:1). Three broad systems are recognised, including marine, estuarine and inland systems, of which the latter is the focus of this work. The South African NWM has seen three iterations of improvements, with the last version, NWM4, including inland wetlands and estuaries. Inland wetlands and rivers are collectively referred to as inland aquatic ecosystems. Regardless of the effort to continuously improve the representation of inland wetlands, a number of studies have showed that the total surface extent of wetlands is poorly represented, with the accuracy of the map estimated at below 54\% compared to finer-scale data (Mbona et al., 2015; Schael et al., 2015; Van Deventer et al., 2016; Melly et al., 2016). The extent of the rivers is based on large quaternary mainstem rivers at a scale of 1:500 000, of which a number of parameters such as seasonality of flow and geomorphic type, are measured (DWAF, 2006; Moolman, 2008; Nel et al., 2011). Internationally, inventories of wetland ecosystems include attributes of the associated floral and faunal species, condition of ecosystems, as well as land ownership, in addition to the ecosystem types (Finlayson and Spiers, 1999). In the NWM4, the presence of a few faunal species (fish, waterbirds and wetland-dependent frogs) were included for the country's first inland aquatic conservation plan, i.e., the National Freshwater Ecosystem Priority Areas (NFEPA) Atlas (Nel et al., 2011; Van Deventer et al., 2016; Nel et al., 2016). In order to create a complete South African Inventory of Inland Aquatic Ecosystems (SAIIAE) for better assessment and planning, improvements to the representation of the inland wetland ecosystem types would be essential, as well as the inclusion of species and other associated information (Margules and Pressey, 2000; Nel et al., 2009; Nel et al., 2011).

The inventorying of inland wetland ecosystems remains a challenge in many countries for a number of reasons. In semi-arid countries such as South Africa, for example, inland wetlands are usually smaller in extent and only a limited number of visibly identifiable indicators can assist in the detection of these systems compared to rivers or inland wetlands with permanent large open water bodies. It has also been previously recognised that South Africa shows a diverse range of climatic zones, from arid to sub-tropical, which result in a diverse range of water, aquatic species and soil chemistry indicators for the identification of inland aquatic ecosystems (Ellery et al., 2009; Ollis et al., 2013). Relative to the terrestrial ecosystems domain, inland aquatic ecosystems have received less attention in the assessment and planning domains ( Nel et al., 2007). Increasing concern about the tremendous losses and degradation of inland aquatic ecosystems in the past 15 years has however supported improved inventorying and monitoring of these ecosystems.
Methods for capturing the extent of inland wetlands are often scale dependent, ranging from field surveying at local scale to regional estimations using predictive modelling or remote sensing classification (GTI and WCS, 2012). Field surveying of inland wetland ecosystems offers the most spatially accurate and detailed understanding of these ecosystems. Through field surveys, detailed information on the hydroperiod, soil and flow characteristics, functionality, condition and presence of species can be recorded. Field surveying becomes costly and impractical for regional to country-wide extents. In contrast, the use of remote sensing has enabled mapping and monitoring of ecosystems at a regional level, though compromising on detail and accuracy. Remote sensing also added the benefit of frequent revisit times which could inform wetland characteristics across multiple seasons and years. The availability of remote-sensing imagery since the Second World War furthered the ability to capture and record geospatial information of inland wetland ecosystems across the world. Remotely-sensed images are generally used in two ways: either for visual interpretation, or image classification. In South Africa, both of these methods have been used. In the early 1990s, the South African Surveys and Mapping Directorate of the Department of Land Affairs supported manual mapping of topographical features, including wetland and river data, from aerial photography, which was later vectorised and converted to shapefile formats (DLA, 2000). Updates to these topographical features are still being done through visual interpretation of imagery and distributed by the National Department of Rural Development and Land Reform: Directorate National Geo-Information (DRDLR:NGI). During the compilation of South African's first National Land Cover (NLC) datasets of 1996, land-cover classes. which included water bodies and wetlands, also used heads-up digitising from Landsat Thematic Mapper images (Thompson, 1996; Fairbanks et al., 2000; Van den Berg et al., 2008). Further divisions of the original NLC water bodies and wetlands classes have also been dependent on visual interpretation of multi-season imagery into subclasses (GTI, 2016).

The use of image classification for the mapping of wetlands in South Africa dates back to soon after the vectorisation of the hydrological datasets from the topographical maps. The space-borne Satellite Pour l'Observation de la Terre-5 (SPOT) and Landsat multispectral imagery were assessed for their ability to map small-scale detailed wetland extents, but were found unsuitable owing to the low spatial resolution of the imagery (Thompson et al., 2002). Regardless of the increase in the spatial resolution of many space-borne sensors since this study, international literature persists in stating that the spatial and spectral resolutions remain deficient for proper mapping and monitoring of inland aquatic ecosystems (Ozesmi and Bauer, 2002; Thompson et al., 2002; Wang et al., 2004; Adam et al., 2010; Hestir et al., 2015). The more recent space-borne sensors, such as WorldView, RapidEye and Sentinel 2A, have increased the ability for detecting and monitoring many aspects of wetlands other than extent. These sensors include a band in the red-edge region of the electromagnetic spectrum which is expected to enhance the monitoring of the essential biodiversity variables of inland aquatic ecosystems, such as floral species discrimination, biomass and biochemicals as surrogates of condition (Cho and Skidmore, 2006; Mutanga and Kumar, 2007; Cho et al., 2008; Turak et al., 2016; Van Deventer et al., 2017). In addition to the optical sensors, space-borne radar technology has been successfully applied in monitoring soil moisture and biomass, which can potentially be used as indicators of wetland functionality and health (Hess et al., 2003; Klemas, 2013; Brisco, 
2014). Radar sensors such as C-band sensors (e.g. the Sentinel $1 \mathrm{~A}$ sensor), are able to sense sub-surface soil moisture up to $5 \mathrm{~cm}$ deep, whereas the L-band sensors (e.g. the Soil Moisture Ocean Salinity or SMOS sensor) could sense up to $30 \mathrm{~cm}$ in the plant's root zone (NASA, 2014). The coarse scale of spaceborne radar imagery of $>10 \mathrm{~km}$ spatial resolution, as well as the expensive nature of airborne imagery, has however limited the application of this technology in the monitoring of inland aquatic ecosystems. The use of remote sensing in the mapping and monitoring of different aspects of inland aquatic ecosystems should therefore be pursued in future, to assess the benefits thereof for South Africa.

The use of digital elevation models (DEMs), derived from the topographical contours and spot heights, has also enabled the use of DEM derivatives in calculating the likelihood of wetlands occurring in the landscape. The earliest work in South Africa was done by Thompson et al. (2002), who compared the ability of the Landscape Wetness Potential, the Topographic Position Index and the Topographic Relative Moisture Index for predicting the occurrence of wetlands for a number of study sites in South Africa (Thompson et al., 2002). The availability of radar-derived DEMs across the world, such as the Shuttle Radar Topography Mission (SRTM), has likely contributed to an increase in similar studies, by expanding the ability to model wetlands using GIS and DEM derivatives to a provincial and country-wide scale (Jarvis et al., 2008). Within the past 5 years, 4 studies in South Africa have modelled wetland extent and types ranging from a metropolitan municipality scale to a country-wide scale (Rivers-Moore and Goodman, 2011; Rivers-Moore and Cowden, 2012a; Rivers-Moore and Cowden, 2012b; Hiestermann and Rivers-Moore, 2015; Van Deventer et al., 2016; Grundling et al., 2016; Melly et al., 2016; Collins, in prep.). Although many of the models did not achieve overall accuracies higher than $70 \%$, the effort contributes to improved understanding and methods of predicting wetlands in the landscape.

In preparation for the third National Biodiversity Assessment of 2018, NBA 2018, a review of existing information, including a questionnaire-based survey, was undertaken to assess whether a SAIIAE can be created building on the efforts of the NWM and river inventories. In particular, we aimed to establish South Africa's first National Wetland Inventory, with the objectives of this paper being to:

- Review which types of information are available for the creation of a SAIIAE

- List and understand the availability of fine-scale wetland data for an update to the NWM

- Recommend future improvements of a SAIIAE for better representation of inland wetland ecosystem types The review focused primarily on the spatial data for the SAIIAE, while a review of the methods for compiling such datasets was not undertaken. It is our intention that the resulting information informs not only the creation of South Africa's first SAIIAE, but also future funding and research teams in devising strategies to improve wetland inventorying in South Africa.

\section{METHODS}

A review of the literature and available data was done, including an electronic questionnaire, a workshop and targeted enquiries to a number of organisations and individuals to obtain information about available data for the SAIIAE. An electronic survey was circulated between October 2015 and February 2016 to more than 500 interested and affected parties (I\&APs) for inland aquatic ecosystems, including the Freshwater Ecosystem Network (FEN), attendees of the National Wetlands Indaba, the Wetland Society (society. wetlands.za.net), provincial wetland forums, the Southern African Society of Aquatic Scientists (SASAqS) and a list administered by Rhodes University (wetlands@lists.ru.ac.za). In addition, a workshop was held at the National Wetlands Indaba of 2015 to discuss the availability of data. Between October 2015 and December 2016, organisations and individuals known to be involved in inland aquatic work and research were also contacted to obtain more recent related data, reports or associated information. Where reports or metadata were lacking or incomplete, follow-up discussions were held to allow for a more informed assessment of the data.

Information was evaluated according to the following two categories:

- Diversity of information available for inclusion in the

SAIIAE:

- Wetland and associated features, including rivers, lakes, artificial wetlands, springs and estuaries (Ollis et al., 2013)

- Faunal and floral species information including

information on invasives

- Environmental setting, including information related to geology, pedology and geomorphic features

- Land ownership and level of protection

- Nature of the inland aquatic ecosystems datasets:

- What was the contribution of river $(\mathrm{km})$ and wetland (ha or $\%$ of surface area of the country) data across sectors?

- What was the approach used in mapping the extent and type of wetlands:

-What was the method used of capturing the data, for example, heads-up digitising, image classification or modelling?

- Which satellite imagery was used for mapping the extent of the wetlands and what is the year and spatial resolution of the images?

- Were the wetlands typed into sub-classes?

- Was the data verified in any way (accuracy assessment)?

- Have the wetlands been assessed for condition and if so was this done through modelling or in-field verification?

The scope of the survey focused on nationally available data sets, although datasets at provincial and regional scales were also considered.

\section{RESULTS}

\section{Diversity of spatial data available for the National Wetland Inventory}

The majority of the 85 records listed as relevant for the SAIIAE were related to inland aquatic ecosystems $(74 \%)$ of which $60 \%$ mapped the extent of inland wetlands at national, provincial and municipal scales (Table 1; Appendix 1). The extent of sub-national data ranged from sub-district to provincial levels with the most datasets (10) received for the KwaZulu-Natal, followed by the Northern Cape (8) and the Western Cape (6) Provinces. Of all the provinces, the Free State and North West had the lowest number of datasets (1), consisting primarily of modelled inland wetlands, except for those listed at a national scale. For the South African islands, only coordinates were listed in a report (Hänel and Chown, 1998). Riverine wetlands are primarily mapped as line features at a scale of 1:500 000 and 1:50 000 (DWA, 2006; DLA:CDSM, 2006). Springs (7 312 point) data, primarily from DRDLR:NGI, complement the extent 
of the inland wetland and river datasets for inland wetland ecosystem types, though this would require mapping and typing of the wetland at the location of the spring. Thermal springs have also been mapped for South Africa (Olivier and Jonker, 2013). The extent of estuary (polygon) data enables the correct mapping of the extent of wetlands and was used in NWM4 to align wetlands to estuaries.

A number of features which indicate the modification of inland wetlands were also mapped, including dams where terrestrial or inland wetlands were converted to aquatic ecosystems. Dams were mapped both by the Department of Water and Sanitation (DWS) and DRDLR:NGI at national level (DLA:CDSM, 2006). Infrastructure, such as canals and roads, contribute to the understanding of the modifications of inland wetlands and rivers, though the consistency and severity of impact are not thoroughly documented. The location of wastewater treatment works (WWTW) and water treatment works (WTW) has been partially mapped by DRDLR:NGI and complemented by the CSIR (CSIR, 2016b), though still considered to be incomplete. In a recent study, the location of aquaculture farms is in the process of being mapped by the Department of Agriculture, Forestry and Fisheries and the Department of Environmental Affairs (DAFF, 2012; Kellerman and Snyman-Van der Walt, 2017; DAFF and DEA, in prep.). The hydrology of the Ekurhuleni Municipality has been mapped, with inclusion of detailed data of infrastructure development within wetlands, for example, the extent of canals (Environomics, 2007). At a local scale, data are therefore less consistent compared to those captured at national scale by DWS and DRDLR:NGI.

Of the species data, more vegetation relevé data from national databases (Sieben et al., 2014; Dayaram, 2017) were received compared to faunal species information, though we acknowledge that we may not have received all available data for South Africa. These relevé datasets are crucial for the inventorying of wetlands since the alluvial vegetation was not mapped consistently in the National Vegetation Map of South Africa (Mucina and Rutherford, 2006). The National Vegetation Database has collated a number of relevés from historical and more recent studies (Dayaram, 2017). Although few datasets were collected on the faunal diversity of inland wetlands, SANBI's species programme collates a variety of datasets related to the distribution of species, from which information on wetland-dependent species can be extracted. In addition, a number of research projects and volunteer atlasing projects provide access to fish, bird and frog data for South Africa (Minter et al., 2004; UCT, 2010; Botts et al., 2011; SAIAB, 2016). Records on aquatic invertebrates are curated by the Albany Museum in the National Freshwater Invertebrate collection whereas the distribution of the habitat of these invertebrates has been modelled at a national scale (Thirion, 2016). Red Data assessments of inland water-dependent species including fish,

\begin{tabular}{|c|c|c|c|c|c|c|c|c|c|c|c|}
\hline \multicolumn{12}{|c|}{$\begin{array}{r}\text { TABLE } 1 \\
\text { Number and types of spatial datasets received for th }\end{array}$} \\
\hline Grouping of datasets & National & EC & FS & GT & KZN & LP & MP & NC & NW & WC & Islands \\
\hline \multicolumn{12}{|c|}{ Number of datasets related to the extent of inland wetland types } \\
\hline Springs & 2 & & & 1 & 1 & & & & & & \\
\hline Rivers & 3 & & & & 1 & & & & & 1 & \\
\hline Wetlands & 8 & 4 & 1 & 5 & 10 & 4 & 3 & 8 & 1 & 6 & 1 \\
\hline Artificial/transformed & 3 & & & & & & & & & & \\
\hline \multicolumn{12}{|c|}{ Number of datasets related to species } \\
\hline \multicolumn{12}{|l|}{ Fauna } \\
\hline Flora & 4 & & & & & & & & & & \\
\hline Invasives & 2 & & & & & & & & & & \\
\hline \multicolumn{12}{|c|}{ Number of datasets related to regional divisions } \\
\hline Climatic regions & 2 & & & & & & & & & & \\
\hline Drainage boundaries & 3 & & & & & & & & & & \\
\hline Ecoregions & 2 & & & & & & & & & & \\
\hline Geomorphological regions & 1 & & & & & & & & & & \\
\hline Water source priority regions & 1 & & & & & & & & & & \\
\hline Substrate & 2 & & & & & & & & & & \\
\hline \multicolumn{12}{|c|}{ Number of datasets related to other aspects of inland wetlands } \\
\hline Water quality & 2 & & & & & & & & & & \\
\hline Monitoring points & 1 & & & & & & & & & & \\
\hline Ownership & 1 & & & & & & & & & & \\
\hline Protected areas & 1 & & & & & & & & & & \\
\hline
\end{tabular}

$E C=$ Eastern Cape $; F S=$ Free State $; G T=$ Gauteng; $K Z N=$ KwaZulu-Natal $L P=$ Limpopo; $M P=$ Mpumalanga $; C=$ Northern Cape; $N W=$ North West; $W C=$ Western Cape. Islands $=$ Marion and Prince Edward Islands of South Africa. Municipal and sub-provincial data sets are grouped into provinces. 
insects, molluscs, crustaceans, reptiles, amphibians, waterbirds, mammals and aquatic plants were done by freshwater ecoregion of southern Africa by the International Union for Conservation of Nature (IUCN) (Darwall et al., 2009; Holland et al., 2012). For many of the faunal assessments, the geographic sampling bias remains to be assessed and Red Data list assessments completed for the NBA 2018.

Two databases of invasive floral species have been collated in South Africa, including the Southern African Plant Invaders Atlas (SAPIA) and the Kotzé database (Henderson, 1979-1998; Kotzé et al., 2010). These collections have mapped invasive floral species for all ecosystems at a 1:50 000 scale and, although not limited to inland wetlands, could provide information on the likelihood of occurrence of invasive species within a certain region. A number of projects are also under way for mapping invasive species at regional scale, using remote sensing by the South African National Space Agency and universities on agricultural weeds (Parthenium hysterophorus weed in KZN; Lantana camara in LP) and Prosopis glandulosa (mesquite) which invades wetland habitats. WorldView-2 imagery has shown promise for mapping mesquite in the NC (Adam et al., 2017). In terms of invasive faunal species, comprehensive records at national scale for invasive faunal species in the inland aquatic domain are deficient. The South African Institute for Aquatic Biodiversity (SAIAB) is custodian of the records of invasive fish species in the country (SAIAB, 2016). Research on invasive faunal species in the inland aquatic domain remains dispersed and dependent on researchers or institutions with interest in this domain (Faulkner et al., 2015).

Other than the datasets which contribute site-specific information and data to inland wetlands, datasets of the broad environmental setting within which inland wetlands occur contribute to the understanding of the context of the wetlands. These include datasets related to climatic regions (Midgley et al., 1994; Schulze et al., 1997; Schulze, 2007; Middleton and Bailey, 2008), drainage regions (Nel et al., 2011; Weepener et al., 2012; Maherry et al., 2013), and strategic resource areas (Colvin et al., 2013; Nel et al., 2017), as well as geomorphological regions (Rowntree and Wadeson, 1999; Partridge et al., 2010). Two landform datasets were previously used for the landscape setting classification of inland wetlands at Level 3, and have previously been included for consideration in NFEPA and NWM4, and have not been listed in this data audit. These include the landforms modelled by the Agricultural Research Council (ARC) and CSIR (Land Type Survey Staff, 1972-2006; Van Deventer et al., 2014), which both require refinement. The availability of other substrate data has been noted in the data audit too, though many of these datasets are mapped at too broad a scale for the purpose of inland wetlands $(\geq 1: 250$ 000). These include the land types and soils data from the ARC as well as alluvial geology data (Soil Survey Staff, 1972-2010.; Land Type Survey Staff, 1972-2006; FAO ISRIC, 2004; Council for Geoscience (CGS), 2017).

In addition to the site-specific and regional characterising of wetlands, a number of datasets are important for the assessment of the headline indicator 'Protection Level' of the NBAs as well as general management and planning (Nel et al., 2011; Driver et al., 2012). These include the South African Protected Areas Database (SAPAD) and conservation areas in the South African Conservation Areas Database (SACAD) that is maintained at a national level by the Department of Environmental Affairs (DEA, 2017). Land parcel information is freely available through the Chief Surveyor-General (http://csg.dla.gov.za) and land ownership information can be obtained through the Registrar of Deeds (www.deed.gov.za), but requires payment.

\section{Nature of the river datasets of South Africa}

A rivers network GIS layer is required in order to map and classify the different river ecosystem types across the country. The Department of Water Affairs (now the Department of Water and Sanitation) 1:500 000 river network was used as a base dataset for the NFEPA project (DWA, 2006) (Fig. 1). Ninety-seven coastal rivers which were associated with the NFEPA estuaries were also added from the 1:50 000 rivers dataset (DLA:CDSM, 2006). A combination of the NFEPA (a)

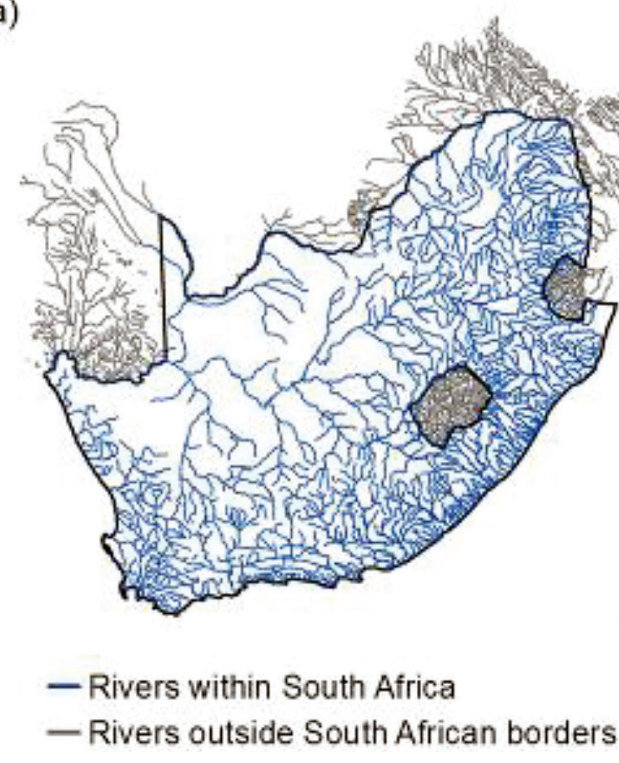

(b)

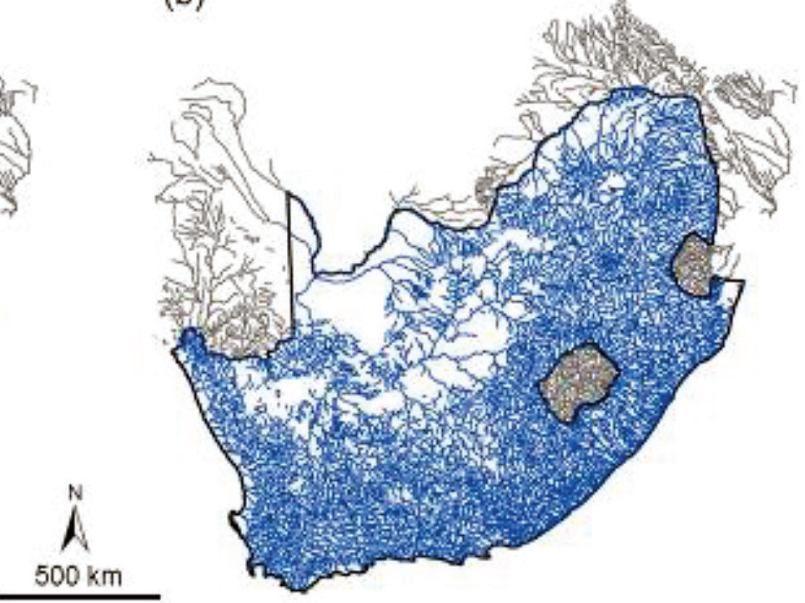

Figure 1

South Africa's 1:500 000 river network showing (a) main rivers and (b) main rivers and their tributaries. Rivers in grey are shared rivers in neighbouring countries 
and additional 1:50 000 rivers which flow into estuaries is in the process of compilation. This dataset was coded to distinguish quaternary catchment mainstems $(77538 \mathrm{~km})$ and tributaries $(95716 \mathrm{~km})$. Mainstems are rivers that pass through a quaternary catchment into a neighbouring quaternary catchment. In situations where no river passes through the quaternary catchment, the longest river system was chosen as the mainstem. All other rivers on the 1:500 000 rivers GIS layer were considered tributaries. Typically, tributaries nest within a single quaternary catchment (Nel et al., 2011).

The 1:500 000 river network is classified into 223 subtypes for the NBA 2011 (Nel et al., 2011). These river ecosystem types can be regarded as coarse-filter surrogates of biodiversity, conserving the diversity of many common and widespread species, and their associated habitats. They are components of rivers with similar physical features such as climate, flow and geomorphology. Under natural conditions, river ecosystem types are expected to share similar biological response potential. They are comprised of distinct combinations of Level 1 ecoregions (Kleynhans et al., 2005), flow variability descriptions and slope categories (Rowntree and Wadeson, 1999; Rowntree et al., 2000; Moolman, 2008). Specifically, delineation included 31 Level 1 ecoregions and four slope categories (mountain streams, upper foothills, lower foothills and lowland rivers). Flow variability was broadly described using two categories: permanent (perennial and seasonal rivers) and not permanent (ephemeral rivers) from the DRDLR:NGI. Whilst NBA 2018 will update the NFEPA rivers network GIS layer with additional 1: 50000 river types that are associated with macro-estuaries and will make use of the NFEPA river type dataset (Nel et al., 2011), longer-term priorities beyond this national assessment will include research on an improved river ecosystem type classification map.

\section{Extent and nature of mapping approaches for inland wetlands}

Between 2009 and 2017 four datasets which depict the extent of inland aquatic ecosystems were generated in South Africa at a country-wide scale (Table 2). Two of these were generated from Landsat imagery for 1990 and 2014 (GTI, 2015; GTI, 2016), one using heads-up digitising from fine-scale colour orthophotography of the years 2012 and 2013 (DRDLR:NGI, 2016) and the NFEPA wetlands which combined wetlands from various sources, including remote sensing, modelled and fine-scale mapped data (Nel et al., 2011; Van Deventer et al., 2016). The extent of the datasets shows the fine-scale mapped wetlands and the combined NFEPA wetlands dataset to contain more than double the extent of wetlands derived through image classification of Landsat data. This can be ascribed to the differences in spatial resolution of Landsat at $30 \mathrm{~m}$ spatial resolution, compared to the $50 \mathrm{~cm}$ spatial resolution images used by the DRDLR:NGI in heads-up digitising. The remotesensing products provide information on historical extent and seasonality of wetlands, as well as an indication of whether the wetlands are natural or artificial in nature. The fine-scale data from the DRDLR:NGI also provides information on whether wetlands are natural or artificial, though seasonality and historical extent are not provided.

\begin{tabular}{|c|c|c|c|}
\hline \multicolumn{4}{|c|}{$\begin{array}{c}\text { TABLE } 2 \\
\text { Extent of inland wetlands (ha) contributed per institution type to the National Wetland Map } 5\end{array}$} \\
\hline Dataset & Sub-class & Surface area (ha) & $\begin{array}{c}\text { Percentage of } \\
\text { South Africa (\%)* }\end{array}$ \\
\hline \multirow[t]{3}{*}{ NLC $2013 / 4$} & Water seasonal & 63152.19 & 0.05 \\
\hline & Water permanent & 391955.49 & 0.32 \\
\hline & Wetlands & 1018745.82 & 0.83 \\
\hline \multicolumn{2}{|l|}{ Total: } & 1473853.50 & 1.21 \\
\hline \multirow[t]{9}{*}{ NLC1990 \& 2014} & Man-made water 1990 only & 68474.88 & 0.06 \\
\hline & Man-made water 2014 only & 62871.03 & 0.05 \\
\hline & Man-made water 1990 and 2014 & 237753.63 & 0.19 \\
\hline & Mining water 1990 only & 8430.12 & 0.01 \\
\hline & Mining water 2014 only & 6353.19 & 0.01 \\
\hline & Mining water 1990 and 2014 & 3734.37 & 0.00 \\
\hline & Natural water (including shadows) 1990 only & 178384.59 & 0.15 \\
\hline & Natural water (including shadows) 2014 only & 33655.14 & 0.03 \\
\hline & Natural water (including shadows) 1990 \& 2014 & 105400.98 & 0.09 \\
\hline \multicolumn{2}{|l|}{ Total: } & 705057.93 & 0.58 \\
\hline \multirow[b]{2}{*}{ NFEPA wetlands (NWM4) } & Artificial & 528188.00 & 0.43 \\
\hline & Natural & 2152118.00 & 1.76 \\
\hline \multicolumn{2}{|l|}{ Total: } & 2680306.00 & 2.20 \\
\hline \multirow[b]{2}{*}{ DRDLR:NGI, 2016} & Artificial & 529252.70 & 0.43 \\
\hline & Natural & 3152249.92 & 2.58 \\
\hline \multicolumn{2}{|l|}{ Total: } & 3681502.63 & 3.02 \\
\hline
\end{tabular}

${ }^{*}$ Calculated from a shapefile totalling 122081147.5 ha for South Africa 
At a sub-national scale, the approaches to wetland data capturing were similar to the national-scale approaches, including remote-sensing image classification as well as finescale mapping of wetlands at various scales (Appendix 1). Few datasets classified wetlands based on image classification other than those generated by GeoTerraImage (Pty) Ltd (GTI) for provincial and municipal departments (GTI, 2010). Only one study assessed the occurrence of wetlands in the Maputaland Coastal Plain of the KZN Province (Grundling et al., 2013a; Grundling et al., 2013b). Similar to the Land Cover data for 2013/4, the image classification of the Maputaland Coastal Plain resulted in an $80 \%$ overall accuracy, using stratifiedrandom sampled points in an error matrix.

The wetland datasets generated through predictive modelling from DEMs ranged in extent from municipal to provincial and country-wide scales. Although initial work focused on predicting occurrence or extent of wetlands or the probability thereof, recent advances showed interest in typing wetlands to hydrogeomorphic units, or Level $4 \mathrm{~A}$ of the Classification System. Many of the studies were primarily dependent on the $90 \mathrm{~m}$ SRTM DEM and other course-resolution data related to environmental variables (Hiestermann and Rivers-Moore, 2015; Van Deventer et al., 2016; Melly et al., 2016). The wetland occurrence modelled for KZN showed a 0.853 area under the curve accuracy, whereas those modelled for the semi-arid Nelson Mandela Bay Metropolitan Municipality were 0.68 (Hiestermann and RiversMoore, 2015; Melly et al., 2016). The comparison between the NFEPA wetlands and wetlands mapped at a fine scale for two districts showed $<50 \%$ agreement on the extent of wetlands $(1.2 \%$ and $42.2 \%)$ and that fine-scale mapping contributed $46 \%$ of wetlands to the City of Cape Town Metropolitan Municipality not mapped by the NFEPA project.

\section{Extent and nature of fine-scale wetland data for South Africa}

Over five million hectares of fine-scale mapped wetland data were received from various governmental, research and private institutions (Table 3 ). The largest contribution to the wetlands map (73\%) was received from the DRDLR:NGI, of which a total of 1552195 ha of natural wetlands were mapped in 2006 and 3152250 ha in 2016 (DLA:CDSM, 2006; DRDLR:NGI, 2016). The second-largest contribution was received from other research institutions (594 089 ha or $12 \%)$, including the Mpumalanga Highveld Wetlands Project (590 391 ha or $99 \%$ of the data received from other research institutions) (Mbona et al., 2015), the Nelson Mandela Bay dataset (Schael et al., 2015), the project on peatlands (Grundling et al., 2017) and research in progress (Rebelo, 2017). Other national, provincial and local municipalities added almost 250000 ha of wetland data, which included, inter alia, the Working for Wetlands data from SANBI between 2004 and 2013 and the Square Kilometre Array (SKA) project (CSIR, 2016a). Wetland data from private companies amounted to more than 300000 ha of wetlands mapped at a fine scale. Other than the Mpumalanga Highveld project, the Cape Action for the Protection of the Environment (CAPE) programme was the single project with the second-highest area of mapped wetlands, of 181876 ha in the WC Province. Five of the eight South African metropolitan municipalities contributed a total of 64623 ha of inland wetlands, including City of Cape Town, City of Johannesburg, City of Tshwane, City of Ekurhuleni and eThekwini (Grundling, 2005a; Grundling, 2005b; Environomics, 2007; Batchelor, 2009;
Snaddon and Day, 2009). South African National Parks (SANParks) have contributed $>6000$ ha of wetland data, of which the majority was mapped and typed based on in-field verification (>90\% of the dataset) (Hayes et al., 2016; Job et al., 2016; Fisher et al., 2017a; Fisher et al., 2017b; Fisher et al., 2017c; Fisher et al., 2017d).

Firstly, the fine-scale mapped inland wetlands from institutions other than the DRDLR:NGI were assessed in more detail. Of the non-DRDLR:NGI wetland data received, more than half of the GT Province (64\%) and nearly half of the MP (47.2\%) and WC Provinces (47.2\%) were mapped by institutions other than the DRDLR:NGI (Fig. 2; Fig. 3). Wetlands mapped at a fine-scale for other provinces covered less than $12 \%$ of their surface areas.

Very few sub-quaternary catchments (SQ4s) were mapped in full, with wetlands typed to categories which could be fully translated to the HGM types of the recent Classification System, and of which the extent and types were verified in-field (Fig. 2; Fig. 3). The WC was the only province with nearly 35000 ha $(<1 \%$ of the country) of wetlands falling into this category (Category A). For $7.1 \%$ of the country, the full extent of the SQ4 was mapped and typed, though in-field verification was not done or only partly done (Category B). Of the remaining, $8.2 \%$ of the country had partially mapped SQ4s of which the typing was partially to fully done (Categories C, D and E), whereas $<1 \%$ of the surface area of the country had SQ4s where wetlands were mapped but not typed (Category F). For the majority of the country (84\%), the wetlands mapped by the DRDLR:NGI are the only available dataset for wetland representation and inland aquatic ecosystem typing.

About half of the sub-national datasets (excluding DRDLR:NGI) received had reports associated with the project and less than a third had metadata information associated with the shapefile. Very few reports and metadata contained detailed information about the wetland data capturing process and the type, scale, date and sources of images used. Metropolitan municipalities often had orthophotography available for

TABLE 3

Total amount of fine-scale mapped wetlands (ha) received from various South African institutions

\begin{tabular}{|l|c|c|}
\hline Institution type & ha* & $\begin{array}{c}\text { Percentage } \\
\text { of total } \\
\text { received (\%) }\end{array}$ \\
\hline $\begin{array}{l}\text { National Government } \\
\text { (DRDLR:NGI) }\end{array}$ & 3681502.6 & 72.8 \\
\hline $\begin{array}{l}\text { Research institutions and } \\
\text { related projects }\end{array}$ & 594089.0 & 11.7 \\
\hline Private companies & 308371.5 & 6.6 \\
\hline $\begin{array}{l}\text { Provincial and local } \\
\text { governments }\end{array}$ & 221800.3 & 4.4 \\
\hline CAPE programme & 181875.6 & 3.6 \\
\hline Metropolitan municipalities & 64623.2 & 1.3 \\
\hline SANParks & 6016.8 & 0.1 \\
\hline $\begin{array}{l}\text { Total amount excluding } \\
\text { DRDLR:NGI }\end{array}$ & 1376776.5 & \\
\hline Total & 5058279.1 & \\
\hline *Values rounded to the first decimal & & \\
\hline
\end{tabular}

${ }^{*}$ Values rounded to the first decimal 


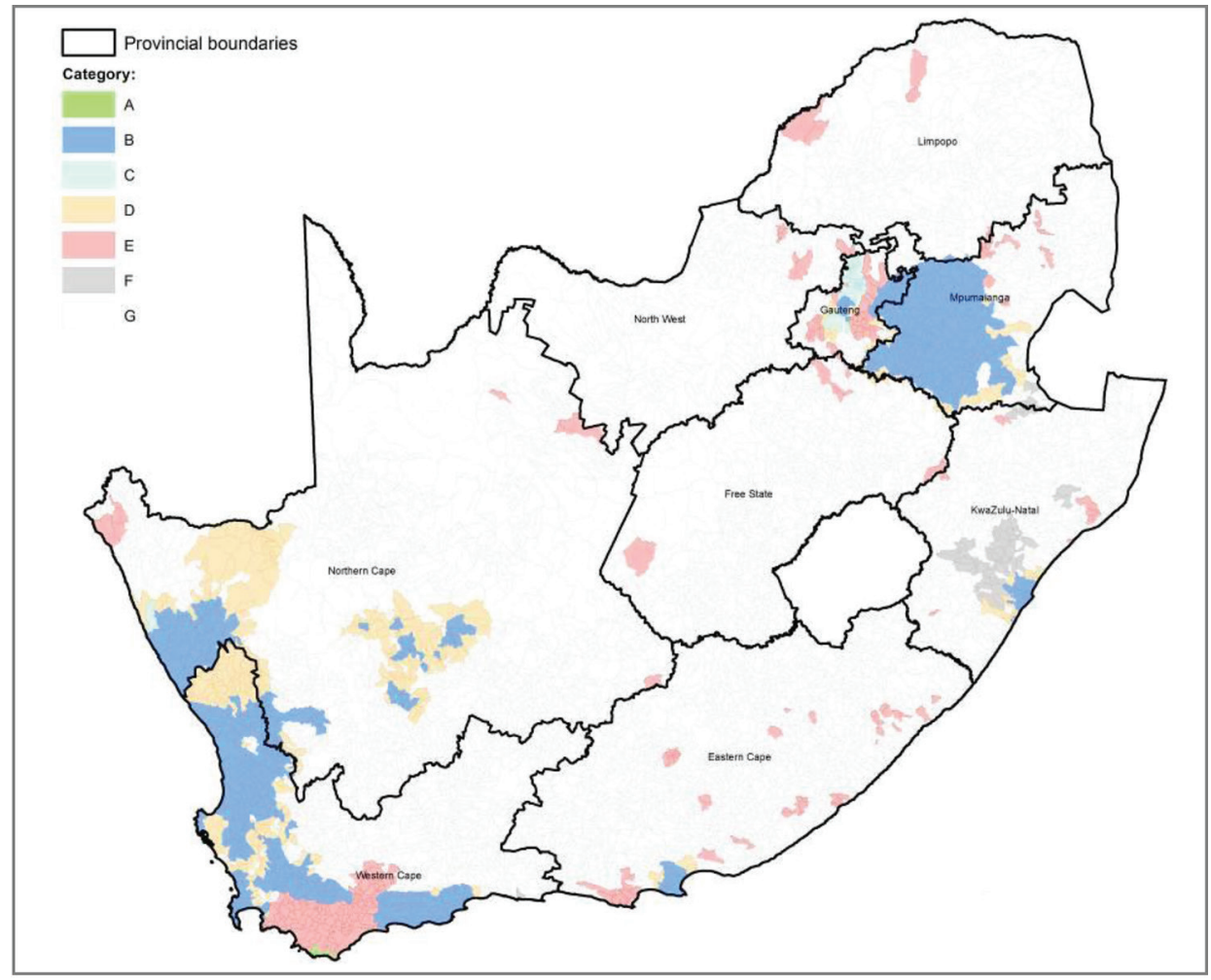

Figure 2

Contributions from institutions to natural inland wetlands. See Fig. 3 for a description of the legend key

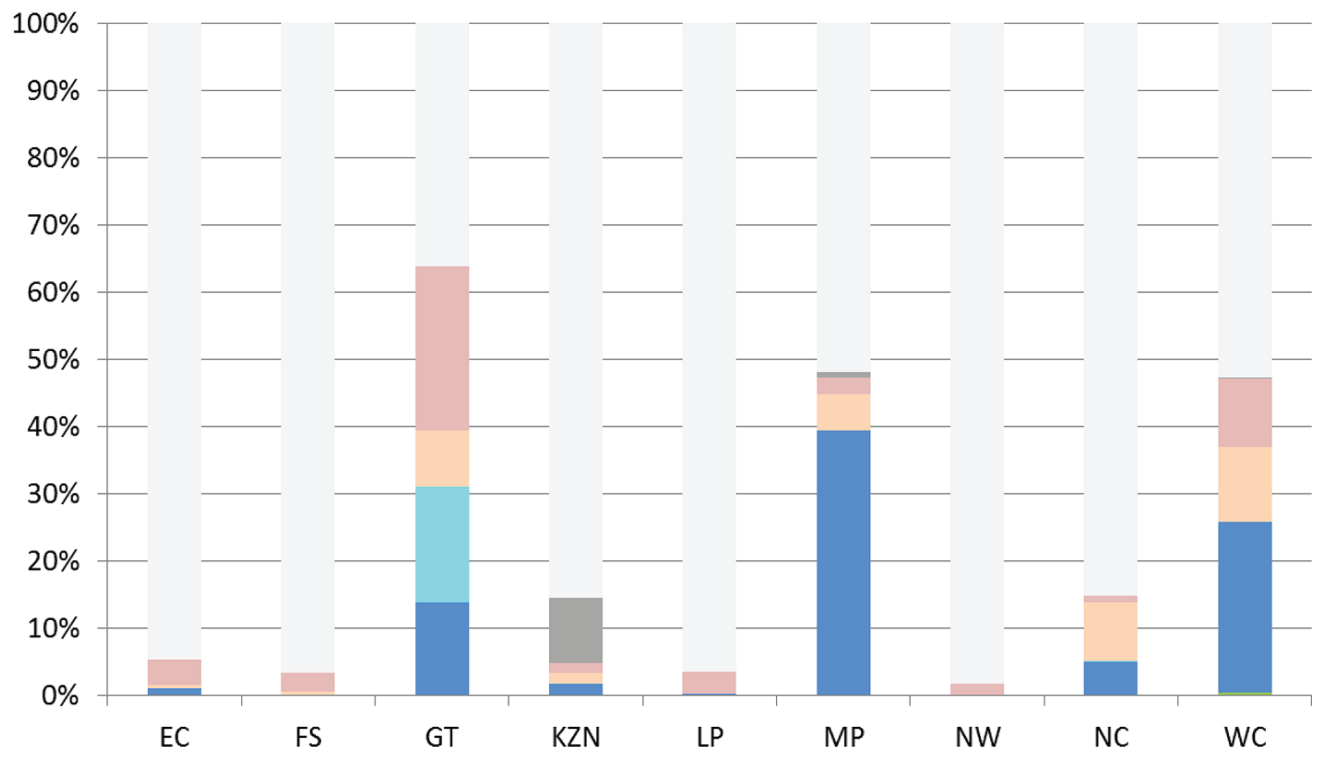

\begin{tabular}{cl}
\hline Key & Description \\
\hline A & SQ4 fully mapped, typed with extent and type verified in-field \\
B & SQ4 fully mapped, typed with extent and type partly verified \\
C & SQ4 largely mapped, typed partially but no in-field verification \\
D & SQ4 partially mapped, typed in full \\
E & SQ4 partially mapped, typed partially \\
F & SQ4 partially to fully mapped but with no types \\
G & SQ4 not mapped at all
\end{tabular}

Figure 3

Categorisation of sub-quaternary (SQ4) catchments of South Africa according to the extent, typing and in-field verification of wetland data received for the national wetland map, given as a percentage of the surface area of each province 
wetlands mapping (Grundling, 2005a; Snaddon et al., 2009; Batchelor, 2009), whereas other studies relied on SPOT and Google Earth. Google Earth imagery has been released since June 2001 and offers historical images for South Africa dating back to approximately 1984 (Europa Technologies United States Department of State Geographer, 2010). The SKA project indicated, however, that the SPOT 2011 mosaic was used for mapping wetlands (CSIR, 2016a). The appropriateness of the season during which the image was taken was not assessed in any study for wetland mapping.

The scale used in heads-up digitising, where indicated, often ranged from 1:5 000 to 1:20 000. None of the reports indicated the method and type of verification done during in-field visits, except for the City of Tshwane and City of Cape Town, of which the latter reports the accuracy of presence and type (75 and 95\% respectively) (Grundling, 20 05a; Snaddon et al., 2009). The method (GPS or auger) used by SANParks in collaboration with Cape Nature and other organisations, added to the improvement of the NWM4 through in-field visits and updates of the extent and types of the NFEPA wetlands for three SQ4s (IDs 9428, 9433, 9434) of the Agulhas National Park as well as the Mountain Zebra and Bontebok National Parks (Job et al., 2016; Fisher et al., 2017a; Fisher et al., 2017b; Fisher et al., 2017c). SANParks is pursuing further work in the remainder of their national parks as well as the SQ4's in which they reside.

Secondly, the DRDLR:NGI fine-scale wetland dataset was explored in more detail. The DRDLR:NGI hydrological polygon datasets (wetlands) are issued at 3-year intervals and data for the country were available for the years 2006, 2009, 2012 and from 2016. For the purpose of the NBA 2018 project, only the 2006 and 2016 data were used as these were readily available as merged and cleaned data sets (Fig. 4). Some of the natural hydrological data mapped by DRDLR:NGI were however river extents and not wetlands and would require evaluation before use in the NWM.

The hydrological data mapped by the DRDLR:NGI in 2006, covered up to $3 \%$ of the surface area of a province (Fig. 5). In four provinces, the DRDLR:NGI mapped between 2 and 3\% of the surface area of the province as wetlands in 2006 (FS, GT, KZN and NC), whereas about $1.6 \%$ of the surface area of MP was mapped as wetlands in 2006, and approximately $1 \%$ for the EC, NW and WC Provinces. The LP Province showed the lowest percentage of its surface area mapped as wetlands (1\%). In three of the nine provinces, the DRDLR:NGI mapped more than $2 \%$ of the surface area as wetlands in 2016, in addition to the wetlands mapped in 2006 (Fig. 5). Although the percentage surface area per province mapped as wetlands in 2016 was lower for the remaining provinces, all provinces showed an increase in the number of wetlands mapped. The extent of wetlands mapped in 2016 for the WC contributed the most to the 2006 data. The surface area of the LP Province mapped by the DRDLR:NGI in both 2006 and 2016 totalled nearly 1\%, the lowest of all the provinces.

For most of the provinces, the 'dam', 'dry water course', 'pans' and 'vlei' categories dominated the feature type classes mapped by the DRDLR:NGI in 2006 and 2016 (Fig. 6). A large number of these feature types can be translated to hydrogeomorphic types of the Classification System at Level 4A (Table 4) and therefore form an important base dataset to the wetland data contributed by the DRDLR:NGI to the NWM.

\section{Condition indices of rivers and inland wetlands}

Two comprehensive national assessments of the ecological condition of South Africa's rivers have been undertaken by the DWS, the first in 1999 (Kleynhans, 2000) and the second in 2011 (DWS, 2014). In each case, an 'aggregated ecological condition category', called Present Ecological State (PES), was developed based on an expert assessment of a set of 6 underlying indicators of ecological condition. Four of these (flow, water quality, instream habitat and stream bank/riparian habitat) were consistent across the 1999 and 2011 assessments. The aggregated ecological condition category reflects the degree of modification from a reference condition of natural, and ranges from natural

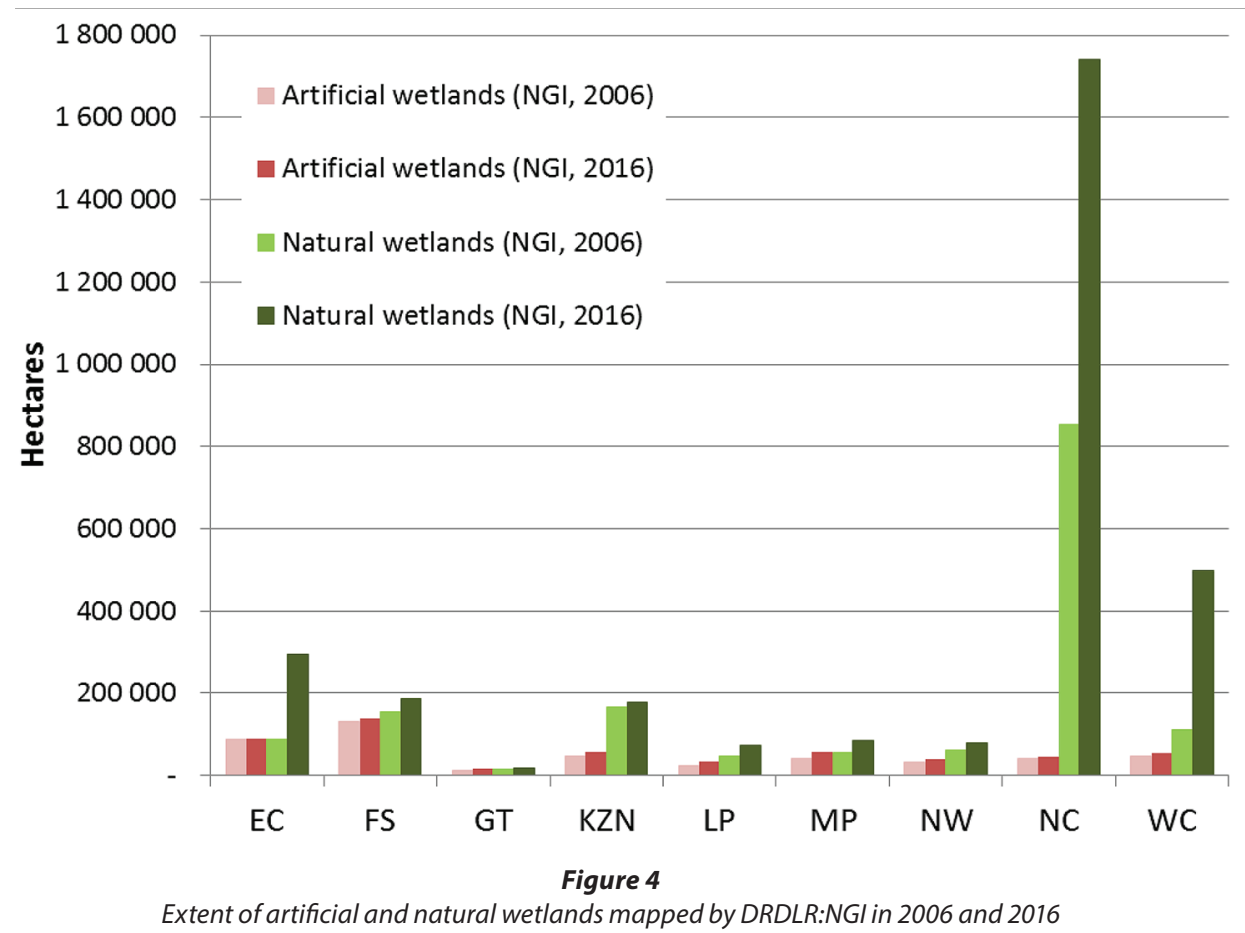

http://dx.doi.org/10.4314/wsa.v44i2.05

Available on website http://www.wrc.org.za

ISSN 1816-7950 (Online) = Water SA Vol. 44 No. 2 April 2018

Published under a Creative Commons Attribution Licence 

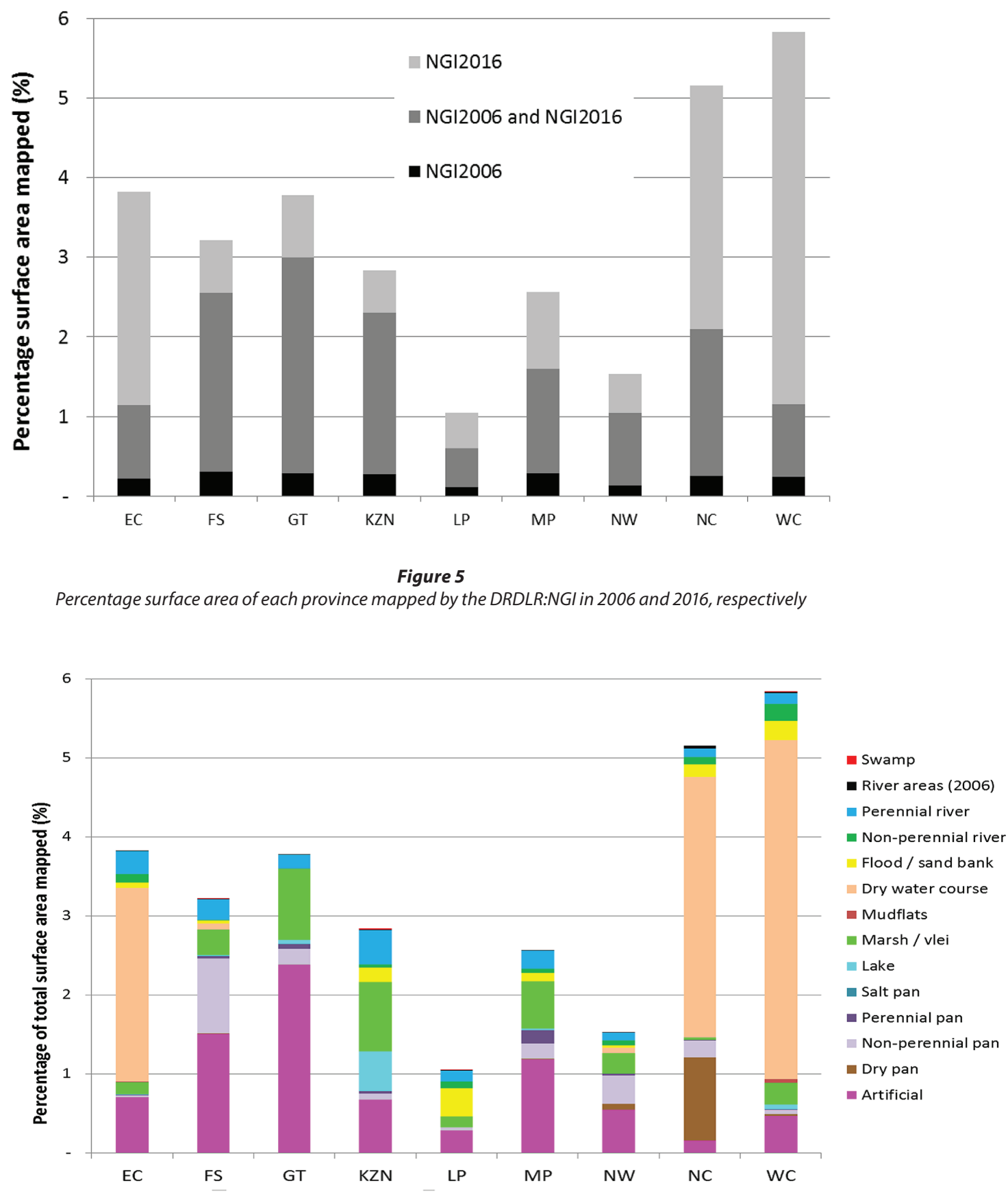

Figure 6

Percentage feature types per province mapped by the DRDLR:NGI (combined data set of 2006 and 2016). Feature types were consolidated for display purposes.

(A) to critically modified (F). The reference condition is the ecological condition that existed before major human modifications to the water resource (the river) and surrounding landscape. For the purposes of NBA 2018 the 2011 PES dataset (i.e. flow, water quality, instream habitat, stream bank/riparian habitat and, longitudinal and lateral connectivity) will be supplemented with modelled data. This dataset will then be used to assess the degradation of rivers across the country.

In the NFEPA and NBA projects of 2011/2, the PES categories were used not only for the rivers, but also for the wetlands as a relative index of the condition of wetlands.
Wetlands that were associated with riverine systems in a poor condition (D, E or F) were assigned the PES category of the river, whereas condition of a non-riverine wetland and the remaining riverine wetlands were ranked primarily based on the percentage of transformed land within a number of buffer distances from the wetland (Nel et al., 2011; Driver et al., 2012). The method allows for a practical implementation of condition ranking at a national scale, and allows back-casting where historical land cover data becomes available, such as the 1990 land cover data set, generated by GTI. The availability of the 1990 and 2013/4 data allows furthermore for change analysis in condition of the surrounding landscape, although 
TABLE 4

Translation of DRDLR:NGI hydrological feature types to HGM wetland types of the Classification System

\begin{tabular}{|l|l|}
\hline DRDLR:NGI feature type & Possible HGM type \\
\hline Closed reservoir & (Artificial) \\
\hline Dam & (Artificial) \\
\hline Dry pan & Depression \\
\hline Dry water course & $\begin{array}{l}\text { River or valley-bottom } \\
\text { wetland }\end{array}$ \\
\hline Fish farm & (Artificial) \\
\hline Flood bank & $\begin{array}{l}\text { River or valley-bottom } \\
\text { wetland }\end{array}$ \\
\hline Lake & Floodplain \\
\hline Large reservoir & (Artificial) \\
\hline Marsh & Natural - to be determined \\
\hline Marsh/vlei & Natural - to be determined \\
\hline Mudflats & Natural - to be determined \\
\hline Non-perennial pan & Depression \\
\hline Non-perennial river & River (channel) \\
\hline Open reservoir & (Artificial) \\
\hline Perennial pan & Depression \\
\hline Perennial river & River (channel) \\
\hline Pool & (Artificial / Natural) \\
\hline Purification plant & (Artificial) \\
\hline River area (2006) & River (channel) \\
\hline Salt pan & Depression \\
\hline Sand bank & $\begin{array}{l}\text { River or valley-bottom } \\
\text { wetland }\end{array}$ \\
\hline Sewerage works & (Artificial) \\
\hline Slimes dam & (Artificial) \\
\hline Swamp & Natural - to be determined \\
\hline Tailings impoundment & (Artificial) \\
\hline Vlei & Natural - to be determined \\
\hline Water tank & (Artificial) \\
\hline
\end{tabular}

not the extent of wetlands. The CAPE programme also modelled the condition of inland wetlands based on the PES categories (Snaddon et al., 2008). A few sub-national, fine-scale wetland datasets have also used the PES scoring for condition assessments of wetlands, and in many cases desktop or rapid assessments were completed (Grundling, 2005a; Snaddon et al., 2009; Batchelor, 2009).

\section{DISCUSSION}

Spatial data related to the SAIIAE originate from a multitude of institutions using a variety of approaches, at a range of spatial scales. National-scale datasets of rivers and wetlands and the monitoring of these are primarily maintained by national government departments (DWS and DRDLR:NGI). A diverse range of organisations contribute to the mapping of regions, species, ownership and protection of wetlands. The coordination and availability of all datasets related to other components of the inventory, including species, condition, regions and monitoring points, is crucial for the improvement of the inventory at all levels. Of these, the extent and the representation of land-use impacts for condition modelling are considered the top priorities.

River ecosystem types were used by the NBA 2018 to represent the diversity of river ecosystems across the country. They are components of rivers with similar physical features (e.g. climate, flow and geomorphology) and under natural conditions they are expected to share similar biological response potential. Ideally, those inland aquatic ecosystems that are currently considered to be in good condition should be selected for the purposes of conserving biodiversity. These natural ecosystems tend to be more self-sustaining, thus requiring less conservation management. The cost of rehabilitating rivers in good condition is also lower than the cost of rehabilitating modified rivers, and the likelihood of success is greater (Nel et al., 2011).

The 1:500 000 river coverage is now almost stable following years of editing procedures, consistency checks, network and name verification and a consolidation process. Users do, however, occasionally report minor errors that are related to shortcomings in the dataset. For example, the reach codes are not stable (i.e. the Arc Macro Language or AML script currently clears the code tables each time it runs). The reach code is a unique identifier for each reach in the stream network. Ideally, the reach codes should remain attached to the same reach except in the case of additions and splits. In addition, it is necessary to check all arcs for errors related to the river names. It must be noted though that most of the unnamed arcs do not have names on the original 1:50 000 maps. In NBA 2018 certain river names will be corrected to reflect the relevant estuary name. The greatest discrepancy is in the classification of rivers as perennial, non-perennial or dry: only $84 \%$ of all the SA arcs are the same as the 1:50 000 classes. Recommendations to improve this dataset include working towards stable reach codes and a comprehensive hydrological dataset (e.g. include variables such as channel elevation, stream velocity, connectivity and smoothed river-run elevation). This would necessitate migrating from ArcInfo to an ArcGIS geodatabase with vertical topology recorded within the rivers network as well as between the rivers network and other datasets. Future developments should also include digital elevation model analysis and applying the updated 1:500 000 verification and reach allocation procedures to the 1:50 000 coverages (DWAF, 2006).

The use of remote sensing for predicting the occurrence of wetlands and sub-types in South Africa has to date been limited to Landsat images. Wetlands modelled using Landsat and SPOT data in the land cover products of South Africa compare poorly to inland wetlands mapped through heads-up digitising. Subsequently this study concurs with existing literature that the spatial and spectral resolution of these sensors are not optimised for mapping the extent of wetlands well (Ozesmi and Bauer, 2002; Thompson et al., 2002; Wang et al., 2004; Adam et al., 2010; Hestir et al., 2015; Grundling et al., 2016). Of the literature studied and cited in this work, to our knowledge no studies have investigated the use of the more recent satellite sensors such as RapidEye, WorldView and the Sentinel series for the mapping and typing of wetlands. Remote-sensing sensors do provide a broad regional overview of attributes of wetlands at regular time intervals and although the extent of wetlands cannot be mapped well, regional to global monitoring of open water extent and quality 
as well as biophysical parameters of biomass and nutrients would be able to contribute a broader view of inland aquatic ecosystem state. The use of the more recently-launched optical sensors as well as radar and radiometry sensors should therefore be investigated to assess whether the red-edge band and finer spatial resolution characteristics of these sensors outperform the traditional SPOT and Landsat sensors.

The DRDLR:NGI forms a significant base dataset for the inland wetlands, contributing approximately $73 \%$ of the available inland wetlands datasets that were received for the NWM5 within the past year. Categories of the DRDLR:NGI hydrological data can be translated to the HGM types. In addition, the DRDLR:NGI is already registered as a data custodian of the topographic core datasets under the South African Spatial Data Infrastructure (SASDI) Act (RSA, 2003), with standards for the capturing of data and obligations to correct errors noted by users. Many other institutions do, however, also contribute to the fine-scale mapping of inland wetlands across South Africa. Inconsistencies in mapping methods, sources of imagery and typing of wetlands may result in differences in extent and type of wetlands which will be challenging and time-consuming to resolve. The diversification of inland wetlands work across institutions, however, optimises cost-expenditure, and would be particularly valuable for accuracy assessments and monitoring which will be ineffective through a national institution. Quality and assurance of wetland extent and HGM type, however, remain a concern when sourced from multiple sources, particularly when no wetland expertise was involved. This study has shown that about $8 \%$ of the country has been mapped and typed to HGM units by wetland specialists (Figs 2 and 3, Categories A and B). The involvement of wetland specialists in the mapping and reviewing of the NWM would be key for future updates. Lateral collaboration between DWS, DRDLR:NGI and SANBI for the updates of the NWM would be crucial, while vertical collaboration between the national institutions and other organisations is essential for verification and monitoring.

Heads-up digitising of wetlands remains the preferred approach at the moment to updates of the National Wetland Map when compared to the remote-sensing modelling methods. The method of heads-up digitising is more accurate, particularly for inland wetlands of smaller extent, palustrine wetlands and certain inland wetland types (arid systems in particular), compared to modelling or data derived from remote-sensing classification methods. Finescale mapping of inland wetlands remains an expensive and time-consuming approach, and a prioritisation strategy would be required to sequentially and continuously update data-poor areas across the expanse of South Africa. Inland wetlands of 9 municipalities have been mapped for the update of the National Wetland Map 5 during the course of 2016-17, in preparation of NBA 2018. Following the completion of NWM5, the data-poor areas should be assessed and wetland mapping considered for these areas. Catchments with gaps of inland wetland data falling in the Strategic Water Source Areas (SWSA) of South Africa or where development pressure is high should be prioritised for fine-scale heads-up digitising of inland wetlands (Nel et al., 2017). Accuracy assessments should also be prioritised within the SWSA and areas of development pressure to ensure these ecosystems receive proper protection and appropriate management strategies.
Our study was limited in the review of available data for the SAIIAE and did not include an extensive review and data capturing of historical inland wetland data. A number of resources exist in the form of hard-copy documents with coordinates of inland wetlands, which would require digitising, for example those of Noble and Hemens (1978), Begg (1988), Cowan and Van Riet (1998) and Dely et al. (1999), to name but a few. In addition a wealth of greyscale satellite imagery is available from the war period (1940) for parts of South Africa and curated by the DRDLR:NGI. Mapping the historical extent of inland wetlands could contribute a better understanding of the amount of wetlands lost or degraded in parts of South Africa. To our knowledge, Begg (1988) is one of the most comprehensive assessments done at a regional scale, quantifying the loss of wetlands in the Mfolozi catchment.

The use of multi-seasonal imagery across various annual hydroperiod cycles should be used for visual interpretation when capturing inland wetlands. Single-season imagery does not always offer a view of the maximum extent of a wetland, following a peak rain season, which may be once in several years for arid systems. Thus far, the updates of the National Wetland Map had insufficient time to investigate multi-season imagery to ensure that the maximum extent of a wetland was captured. These issues remain to be resolved in future strategies and standards for either heads-up digitising and/or monitoring. The improvement of both the spatial resolution, time-series data from multiple seasons and years, as well as accuracy of environmental data and space-borne sensors offer new opportunities to investigate modelling and remote-sensing classification as alternative methods to finescale mapping in data-poor areas. The approaches should complement one another in a well-developed strategy for updating the National Freshwater Inventory and National Wetland Map within a regular seasonal or annual cycle. Rules for integration of the datasets should be documented with choices of updating some parts of the data and integrating these in future updates.

Since the NFEPA and NBA 2011 projects, a number of datasets have been generated which can be used for the confirmation or classification of a relative condition index for riverine and non-riverine wetlands. These include the location of WTW, WWTW and aquaculture pond as artificial wetlands, but also the prevalence of alien invasive species and water pollution. The completeness of these datasets for use at a national level, as well as their appropriateness of use for modelling condition, should be assessed in future. In addition, methods to better represent the temporal variation and intensity of land-use impacts on wetlands should be investigated. Although a number of research projects have investigated the ability of the new space-borne sensors for the classification of invasive species (e.g. Adam et al., 2017), this paper has not attempted to provide a comprehensive review of the available literature or datasets in this regard. Further effort should be made to compile a spatially coherent dataset of pressures on the inland aquatic ecosystems.

In conclusion, the diversity of information and datasets related to inland wetlands for a South African National Wetland Inventory remains dispersed and uncoordinated. Effort should be directed toward the collaboration at national government level needed to coordinate the collation and curation of wetland data-sets. While a greater amount of the funding was allocated within the past 10 years towards the ecosystem type mapping and improvements thereof, the 
next 10 years may require more focus on the implementation of monitoring of the ecosystem types, the collation and monitoring of species and invasives and the refinement and monitoring of impacts on wetlands.

\section{CONCLUSION}

South Africa is in the process of updating its National Wetland Map (NWM) and creating its first National Freshwater Inventory for the National Biodiversity Assessment for 2018. Recognition is given to the multiple data sources contributing to the South African National Wetland Inventory (SAIIAE) and NWM and the different approaches used: fine-scale mapping and modelling from digital elevation models (DEMs) or remote-sensing image classification. This review paper provides an overview of datasets related to regional setting, species, wetland extent and types, protection, monitoring and condition for use in the NBA 2018. The number of hectares of wetlands available for NWM5 is listed and the amount of data which include sub-types are indicated. Recommendations are made for the improvement of the South African National Wetland Inventory and Map.

\section{ACKNOWLEDGEMENTS}

This study was funded by the Parliamentary Grant funding of the CSIR (Project EEEO053), funding allocated by the South African National Biodiversity Institute (SANBI) to the National Biodiversity Assessment for 2018 (NBA 2018) and the Water Research Commission (WRC) under the project WRC K5/2546 'Enabling more responsive policy and decision making in relation to wetlands through improving the quality of spatial wetland data in South Africa'. We are tremendously grateful to the two reviewers who provided comments and suggestions to the improvement of this manuscript.

\section{REFERENCES}

ADAM E, MURERIWA N and NEWETE S (2017) Mapping Prosopis glandulosa (mesquite) in the semi-arid environment of South Africa using high-resolution WorldView-2 imagery and machine learning classifiers. J. Arid Environ. 1-9. https://doi.org/10.1016/j. jaridenv.2017.05.001

ADAM E, MUTANGA O and RUGEGE D (2010) Multispectral and hyperspectral remote sensing for identification and mapping of wetland vegetation: a review. Wetl. Ecol. Manage. 18 281-296. https://doi.org/10.1007/s11273-009-9169-z

BATCHELOR A (2009) Wetland and riparian protection and management plan for the City of Johannesburg. Report from Wetland Consulting Services (Pty) Ltd to the City of Johannesburg, Jane Eagle. Wetland Consultancy Services (WCS), Pretoria, South Africa.

BEGG GW (1988) The wetlands of Natal (Part 2): The distribution, extent and status of wetlands in the Mfolozi catchment. Natal Town and Regional Planning Commission Report 71, Pietermaritzburg, South Africa.

BOTTS EA, ERASMUS BFN and ALEXANDER GJ (2011) Geographic sampling bias in the South African Frog Atlas Project: implications for conservation planning. Biodivers. Conserv. 20 119-139. https:// doi.org/10.1007/s10531-010-9950-6

CHO MA, SOBHAN I, SKIDMORE AK and DE LEEUW J (2008) Discriminating species using hyperspectral indices at leaf and canopy scales. In: The International Archives of the Photogrammetry, Remote Sensing and Spatial Information Sciences. Vol. XXXVII. Part B7. Beijing URL: http://www.isprs.org/ proceedings/XXXVII/congress/7_pdf/3_WG-VII-3/28.pdf.

CHO MA and SKIDMORE AK (2006) A new technique for extracting the red edge position from hyperspectral data: The linear extrapolation method. Remote Sens. Environ. 101 (2) 181-193. https://doi.org/10.1016/j.rse.2005.12.011

COLLINS N (in prep.) Freshwater component of the Free State Biodiversity Plan. Free State Department of Economic, Small Business Development, Tourism and Environmental Affairs (FS DESTEA), Bloemfontein, South Africa.

COLVIN C, NOBULA S, HAINES I, NEL JL, LE MAITRE DC and SMITH J (2013) An introduction to South Africa's water source areas: the $8 \%$ land area that provides $50 \%$ of our surface water. WWF report. URL: http://www.wwf.org.za/?9202/Journey-ofWater-shows-South-Africans-where-water-comes-from (Accessed 8 August 2017).

CGS (Council for Geoscience) (2017) Geology shapefile data at a scale of 1:250 000. CGS, Pretoria, South Africa.

CSIR (Council for Scientific and Industrial Research) (2016a) Integrated Environmental Management Plan for the South African mid-frequency array of SKA Phase 1 - Aquatic Ecosystems Assessment of the SKA Phase 1 in South Africa. CSIR Report Number: CSIR/02100/EMS/ER/2016/15241/B. CSIR, Pretoria, South Africa.

CSIR (Council for Scientific and Industrial Research) (2016b) Point locations of Wastewater Treatment Works (WWTW) and Water Treatment Works (WTW) mapped at a scale of 1:50 000. CSIR, Pretoria.

COWAN GI and VAN RIET W (1998) A Directory of South African Wetlands. Department of Environmental Affairs and Tourism, Pretoria.

DARWALL WRT, SMITH KG, TWEDDEL D, SKELTON P and SKELTON P (2009) The Status and Distribution of Freshwater Biodiversity in Southern Africa. IUCN, Gland.

DAYARAM A (2017) Extraction of wetland plots from the National Vegetation Database (NVD). Report Number: SANBI/BAM/ VM/2017/01. South African National Biodiversity Institute (SANBI), Pretoria.

DELY JL, KOTZE DC, QUINN NM and MANDER JJ (1999) A pilot project to compile an inventory and classification of wetlands in the Natal Drakensberg Park. Department of Environmental Affairs and Tourism, Pretoria.

DAFF (Department of Agriculture, Forestry and Fisheries, South Africa) (2012) South Africa's Aquaculture Yearbook 2012. DAFF, Pretoria. 60 pp.

DAFF and DEA (Department of Agriculture, Forestry and Fisheries, and Department of Environmental Affairs, South Africa) (in prep.) National Strategic Environmental Assessment for Aquaculture Development in South Africa. DAFF/DEA, Pretoria.

DEA (Department of Environmental Affairs) (2017) Protected Areas and Conservation Areas (PACA) Database: Classification and definition of protected areas and conservation areas. Directorate Enterprise Geospatial Information Management, Department of Environmental Affairs, Pretoria, South Africa. URL: http://egis. environment.gov.za (Accessed 24 July 2017).

DLA (Department of Land Affairs) (2000) The Chief Directorate Surveys and Mapping. 80 Years Anniversary 1920-2000. Department of Land Affairs (DLA), Cape Town.

DLA:CDSM (Department of Land Affairs: Chief Directorate of Surveys and Mapping) (2006) Hydrological polygon and river line shapefiles mapped from the 1:50 000 topographical maps. DLA:CDSM, Cape Town.

DRDLR:NGI (Department Of Rural Development And Land Reform: National Geo-Information) (2016) Provincial geodatabases of hydrological databases exported from GeoMedia in March 2016. DRDLR:NGI, Cape Town, South Africa.

DWA (Department of Water Affairs, South Africa) (2006) South African dams and river line shapefiles mapped at 1:500 000 . URL: http://www.dwaf.gov.za/iwqs/gis_data/river/rivs500k.html (Accessed 8 August 2017).

DWAF (Department of Water Affairs and Forestry, South Africa) (2006) The construction of a hydrologically-correct, annotated 1:500 000 spatial dataset of the rivers of South Africa and contiguous basins. Report Number N/0000/00/REH/0701. DWAF: Resource Quality Services, Pretoria.

DWS (Department of Water and Sanitation) (2014) A Desktop Assessment of the Present Ecological State, Ecological Importance and Ecological Sensitivity per Sub-Quaternary Reaches for 
Secondary Catchments in South Africa. Secondary: W5 (Example). URL: http://www.Dwa.Gov.Za/Iwqs/Rhp/Eco/Peseismodel.Aspx. (Accessed 24 July 2017).

DRIVER A, MAZE K, ROUGET M, LOMBARD AT, NEL JL, TURPIE JK, COWLING RM, DESMET P, GOODMAN P, HARRIS J, JONAS Z, REYERS B, SINK K and STRAUSS T (2005) National Spatial Biodiversity Assessment 2004: Priorities for Biodiversity Conservation in South Africa. South African National Biodiversity Institute (SANBI), Pretoria, South Africa.

DRIVER A, SINK KJ, NEL JL, HOLNESS S, VAN NIEKERK L, DANIELS F, JONAS Z, MAJIEDT P, HARRIS L and MAZE K (2012) National Biodiversity Assessment 2011: An assessment of South Africa's biodiversity and ecosystems. Synthesis report. South African National Biodiversity Institute (SANBI) and Department of Environmental Affairs (DEA), Pretoria, South Africa.

ELLERY WN, KOTZE DC, MCCARTHY TS, TOOTH S, GRENFELL M, BECKENDAHL H, QUINN N and RAMSAY L (2009) WETOrigins: The origin and evolution of wetlands. WRC Report No. TT 334/09. Water Research Commission, Pretoria, South Africa.

ENVIRONOMICS (2007) Environmental Management Framework for Ekurhuleni. Environomics, Pretoria, South Africa.

EUROPA TECHNOLOGIES UNITED STATES DEPARTMENT OF STATE GEOGRAPHER (2010) Google \& Tele Atlas: Google Earth Imagery. URL: https://earth.google.com/ (Accessed 24 July 2017).

FAIRBANKS DHK, THOMPSON MW, VINK DE, NEWBY TS, VAN DEN BERG HM and EVERARD DA (2000) The South African Land-cover characteristics database: a synopsis of the landscape. $S$. Afr. J. Sci. 96 69-82.

FAULKNER KT, SPEAR D, ROBERTSON MP, ROUGET M and WILSON JRU (2015) An assessment of the information content of South African alien species database. Bothalia 45 (1) 11 pages.

FINLAYSON CM and SPIERS AG (1999) Global review of wetland resources and priorities for wetland inventory. Supervising Scientist Report 144, Wetlands International Publication 53 Supervising Scientist, Canberra, Australia. https://doi.org/10.1071/ MF99098

FINLAYSON CM, DAVIDSON NC, SPIERS AG and STEVENSON NJ (1999) Global wetland inventory - current status and future priorities. Mar. Freshwater Res. 50 717-727.

FISHER RC, ADAMS TA and EBRAHIM Z (2017a) NFEPA Wetland Groundtruthing in Bontebok National Park. Wetlands data set compiled by the South African National Parks: Scientific Services, Cape Research Centre. SANParks, Cape Town, South Africa.

FISHER RC, GOUWS J, ADAMS TA and EBRAHIM Z (2017b) NFEPA Wetland Groundtruthing for catchment SQ4 ID 9434 on the Agulhas Plain. Wetlands data set compiled by the South African National Parks: Scientific Services, Cape Research Centre. SANParks, Cape Town.

FISHER RC, GOUWS J, JOB N, NIEWOUDT H, EBRAHIM Z and ADAMS TA (2017c) NFEPA Wetland Groundtruthing for the Ratel River catchment (SQ4 ID 9428) on the Agulhas Plain. Wetlands data set compiled by the South African National Parks: Scientific Services, Cape Research Centre. SANParks, Cape Town.

FISHER RC, GOUWS J, NIEWOUDT H, ADAMS TA and EBRAHIM Z (2017d) Wetland Groundtruthing for catchment SQ4 ID 9433 on the Agulhas Plain. Wetlands data set compiled by the South African National Parks: Scientific Services, Cape Research Centre. SANParks, Cape Town.

FAO ISRIC (Food and Agricultural Organisation and International Soil Reference and Information Centre) (2004) Soil and Terrain Database (SOTER). FAO ISRIC, Rome, Italy. URL: geonode.isric. org/layers/geonode:soter_za_map_unit (Accessed 8 August 2017)

GTI (Geoterraimage Pty Ltd) (2010) 2008 KZN Province Land-Cover Mapping (from SPOT5 Satellite Imagery Circa 2008). Data Users Report and Meta Data (Version 1.0). GTI, Pretoria, South Africa.

GTI (Geoterraimage Pty Ltd) (2015) 2013-2014 South African National Land-Cover Dataset. GTI, Pretoria, South Africa.

GTI (Geoterraimage Pty Ltd) (2016) South Africa Land Cover Water Feature Splits (1990 - 2013/14). Data Users Report and Meta Data (Version 2). GTI, Pretoria, South Africa.

GTI and WCS (Geoterraimage Pty Ltd and Wetland Consultancy Services) (2012) Wetland Mapping Guidelines for South Africa.
Report prepared for SANBI. GTI \& WCS, Pretoria, South Africa. GRUNDLING AT (2005a) Development of a preliminary inventory and status assessment of wetlands in the Northern Tshwane study area. Report GW/A/2005/43 compiled by the Agricultural Research Council: Institute for Soil, Climate and Water (ARC:ISCW) for the City of Tshwane. ARC:ISCW, Pretoria.

GRUNDLING AT (2005b) Development of a preliminary inventory and status assessment of wetlands in the Southern Tshwane study area. Report compiled by the Agricultural Research Council: Institute for Soil, Climate and Water (ARC:ISCW) for the City of Tshwane. ARC-ISCW, Pretoria.

GRUNDLING AT, VAN DEN BERG EC and PRETORIUS ML (2013a) Influence of regional environmental factors on the distribution, characteristics and functioning of hydrogeomorphic wetland types on the Maputaland Coastal Plain, KwaZulu-Natal, South Africa. (WRC) Report No. 1923/1/14. WRC, Pretoria, South Africa. Water Research Commission

GRUNDLING AT, VAN DEN BERG EC and PRICE JS (2013b) Assessing the distribution of wetlands over wet and dry periods and land-use change on the Maputaland Coastal Plain, northeastern KwaZulu-Natal, South Africa. S. Afr. J. Geomatics 2 (2) $120-139$.

GRUNDLING P, GRUNDLING AT, PRETORIUS L, MULDERS J and MITCHELL S (2017) South African peatlands: ecohydrological characteristics and socio-economic value. WRC Report No. 2346/1/17. Water Research Commission, Pretoria.

GRUNDLING PL, GRUNDLING AT, LINSTROM A, VAN DEN BERG H, GROOTJANS AP, PRICE JS, ENGELBRECHT J, OTTO D, RIDDEL E and LORENZ S (2016) The wetlands of the Kruger, Mapungubwe and Marakele National Parks: Characterisation, classification and inventory (Reference number: GRUNP654). Report to the South African National Parks (SANParks). SANParks, Skukuza, South Africa.

HÄNEL C and CHOWN S (1998) An Introductory Guide to the Marion and Prince Edward Island. 50 Years After Annexation. Department of Environmental Affairs and Tourism (DEAT), Pretoria, South Africa. 80 pp.

HAYES JS, KRUGER N, DE KLERK J and MAPHANGA B (2016) A wetland survey in selected areas of the Knysna Protected Environment. Report from the South African National Parks (SANParks), Scientific Services, Knysna. SANParks, Knysna, South Africa.

HENDERSON L (1979-1998) The Southern African Plant Invaders Atlas (SAPIA) Phase I. ARC, Pretoria.

HESTIR EL, BRANDO VE, BRESCIANI M, GIARDINO C, MATTA E, VILLA P and DEKKER AG (2015) Measuring freshwater aquatic ecosystems: The need for a hyperspectral global mapping satellite mission. Remote Sens. Environ. 167 181-195. https://doi. org/10.1016/j.rse.2015.05.023

HIESTERMANN J and RIVERS-MOORE N (2015) Predictive modelling of wetland occurrence in KwaZulu-Natal, South Africa. S. Afr. J. Sci. 111 (7/8), 10 pages. http://dx.doi.org/10.17159/.

HOLLAND RA, DARWALL WRT and SMIT KG (2012) Conservation priorities for freshwater biodiversity: the Key Biodiversity Area approach refined and tested for continental Africa. Biol. Conserv. 148 167-179. https://doi.org/10.1016/j.biocon.2012.01.016

JARVIS A, REUTER HI, NELSON A and GUEVARA E (2008) Holefilled SRTM for the globe version 4, available from the Consultative Group for International Agriculture Research - Consortium for Spatial Information (CGIAR-CSI) Shuttle Radar Topography Mapper (SRTM) 90 m database. URL: http:/www.cgiar-csi.org/ Data (Accessed 24 July 2017).

JOB N, ROUX DR, RAMABULANA L, BAARD J, AHRENDS B, BEZUIDENHOUT H, COLE N, SITHOLE H, DU TOIT L and CRUYWAGEN K (2016) Wetland inventory of Mountain Zebra National Park. South African National Parks (SANParks) Scientific Report 05/2016. SANParks, Cape Town.

KELLERMAN L and SNYMAN-VAN DER WALT L (2017) National Strategic Environmental Assessment for Aquaculture Development in South Africa. Draft report and data. CSIR, Pretoria, South Africa.

KLEYNHANS CJ (2000) Desktop estimates of the ecological importance and sensitivity categories (EISC), default ecological management classes (DEMC), present ecological status categories 
(PESC), present attainable ecological management classes (present AEMC), and best attainable ecological management class (best AEMC) for quaternary catchments in South Africa. Department of Water Affairs and Forestry: Institute for Water Quality Studies (DWAF:IWQS), Pretoria, South Africa.

KLEYNHANS CJ, THIRION C and MOOLMAN J (2005) A Level I Ecoregion Classification System for South Africa, Lesotho and Swaziland. Department of Water Affairs and Forestry: Institute for Water Quality Studies (DWAF:IWQS), Pretoria.

KOTZE D, MARNEWECK G, BATCHELOR A, LINDLEY D and COLLINS N (2009) WET-EcoServices: A technique for rapidly assessing ecosystem services supplied by wetlands. WRC Report No. TT339/09. Water Research Commission, Pretoria, South Africa.

KOTZÉ I, BEUKES H, VAN DEN BERG E and NEWBY T (2010) National Invasive Alien Plant Survey. Report GW/A/2010/21. Agricultural Research Council (ARC), Pretoria.

LAND TYPE SURVEY STAFF (1972-2006) Land Types of South Africa. Digital Map (1:250 000 Scale). Agricultural Research Council: Institute for Soil (ARC:ISCW), Climate and Water, Pretoria.

MAHERRY A, HORAN MJC, SMITH-ADAO LB, VAN DEVENTER H, NEL JL, SCHULZE RE and KUNZ RP (2013) Delineating river network quinary catchments for South Africa and allocating daily hydrological information. WRC Report No. 2020/1/12. Water Research Commission, Pretoria.

MARGULES CR and PRESSEY RL (2000) Systematic conservation planning. Nature 405 243-253. https://doi.org/10.1038/35012251

MBONA N, JOB N, SMITH J, NEL J, HOLNESS S, MEMANI S and DINI J (2015) Supporting better decision-making around coal mining in the Mpumalanga Highveld through the development of mapping tools and refinement of spatial data on wetlands. WRC Report No. TT614/14. Water Research Commission, Pretoria.

MELLY BL, SCHAEL DM, RIVERS-MOORE N and GAMA PT (2016) Mapping ephemeral wetlands: manual digitisation and logistic regression modelling in Nelson Mandela Bay Municipality, South Africa. Wetl. Ecol. Manage.

MIDDLETON BJ and BAILEY AK (2008) Water resources of South Africa, 2005 study (WR2005) and book of maps. WRC Report No. TT381/08 \& TT382/08. Water Research Commission, Pretoria.

MIDGLEY DC, PITMAN WV and MIDDLETON BJ (1994) Surface water resources of South Africa 1990. Volumes 1 to 6. WRC Report Numbers 298/1/94 to 298/6.2/94. Water Research Commission, Pretoria.

MINTER LR, BURGER M, HARRISON JA, BRAACK HH, BISHOP PJ and KLOEPFER D (2004) Atlas and Red Data Book of the Frogs of South Africa, Lesotho and Swaziland. Volume 9 SI/MAB Series. Smithsonian Institution, Monitoring and Assessment of Biodiversity Program, Cornell University, United State of America. 360 pp.

MITTERMEIER RA, ROBLES-GIL P and MITTERMEIER CG (1997) Megadiversity. Earth's Biological Wealthiest Nations. CEMEX/ Agrupaciaon, Sierra Madre, Mexico City, Mexico.

MOOLMAN J (2008) River long profiles aid in ecological planning. PositionIT Jan/Feb (43-45).

MUCINA L and RUTHERFORD MC (2006) The Vegetation of South Africa, Lesotho and Swaziland. South African National Biodiversity Institute (SANBI) Strelizia, Pretoria, South Africa.

MUTANGA O and KUMAR L (2007) Estimating and mapping grass phosphorus concentration in an African savanna using hyperspectral image data. Int. J. Remote Sens. 28 (21) 4897-4911. https://doi.org/10.1080/01431160701253253

NATIONAL AERONAUTICS AND SPACE ADMINISTRATION (NASA) (2014) Soil moisture active passive (SMAP) handbook. Mapping soil moisture and freeze/thaw from space. URL: smap.jpl. nasa.gov/mission/description (Accessed 8 June 2017).

NEL JL, MURRAY KM, MAHERRY AM, PETERSEN CP, ROUX DJ, DRIVER A, HILL L, VAN DEVENTER H, FUNKE N, SWARTZ ER, SMITH-ADAO LB, MBONA N, DOWNSBOROUGH L and NIENABER S (2011) Technical report: National Freshwater Ecosystem Priority Areas Project. WRC Report No. 1801/2/11. Water Research Commission, Pretoria.

NEL JL, ROUX DJ, ABELL R, ASHTON PJ, COWLING RM, HIGGINS JV, THIEME M and VIERS JH (2009) Progress and challenges in freshwater conservation planning. Aquat. Conserv.: Mar.
Freshwater Ecosyst. 19 474-485. https://doi.org/10.1002/aqc.1010 NEL JL, ROUX DJ, MAREE G, KLEYNHANS CJ, MOOLMAN J, REYERS B, ROUGET M and COWLING RM (2007) Rivers in peril inside and outside protected areas: a systematic approach to conservation assessment of river ecosystems. Diversity Distrib. 13 341-352. https://doi.org/10.1111/j.1472-4642.2007.00308.x

NEL JL, LE MAITRE D, ROUX DJ, COLVIN C, SMITH JS, SMITHADAO LB, MAHERRY A and SITAS N (2017) Strategic water source areas for urban water security: Making the connection between protecting ecosystems and benefiting from their services. Ecosyst. Serv. https://doi.org/10.1016/j.ecoser.2017.07.013 https://doi. org/10.1016/j.ecoser.2017.07.013

NEL JL, ROUX DJ, DRIVER A, HILL L, MAHERRY A, SNADDON K, PETERSEN C, SMITH-ADAO LB, VAN DEVENTER H and REYERS B (2016) Cooperative implementation of a systematic freshwater conservation plan through knowledge-coproduction and boundary work. Conserv. Biol. 30 (1) 176-188. https://doi. org/10.1111/cobi.12560

NOBLE RG and HEMENS J (1978) Inland water ecosystems in South Africa - a review of research needs. South African National Scientific Programmes Report No. 34. Council for Scientific and Industrial Research (CSIR), Pretoria.

O'KEEFFE JH (1985) The conservation of South African rivers. South African National Scientific Programme Report No 121. Council for Scientific and Industrial Research (CSIR), Pretoria, South Africa.

OLIVIER J and JONKER N (2013) Optimal utilisation of thermal springs in South Africa. WRC Report No. TT 577/13. Water Research Commission, Pretoria.

OLLIS DJ, SNADDON CD, JOB NM and MBONA N (2013) Classification system for wetlands and other aquatic ecosystems in South Africa. User manual: inland systems. SANBI Biodiversity Series 22. South African National Biodiversity Institute (SANBI), Pretoria.

OZESMI SL and BAUER ME (2002) Satellite remote sensing of wetlands. Wetl. Ecol. Manage. 10 381-402. https://doi. org/10.1023/A:1020908432489

PARTRIDGE TC, DOLLAR ESJ, MOOLMAN J and DOLLAR LH (2010) The geomorphic provinces of South Africa, Lesotho and Swaziland: A physiographic subdivision for earth and environmental scientists. Trans. R. Soc. S. Afr. 65 (1) 1-47. https:// doi.org/10.1080/00359191003652033

REBELO AJ (2017) Ecosystem services of Palmiet wetlands: The role of ecosystem composition \& function. $\mathrm{PhD}$ thesis, University of Antwerp, Belgium.

RIVERS-MOORE N and COWDEN C (2012a) Probabilistic modelling of wetland condition. WRC Report No. KV 298/12. Water Research Commission, Pretoria. https://doi.org/10.1007/s11273-012-9271-5

RIVERS-MOORE NA and COWDEN C (2012b) Regional prediction of wetland degradation in South Africa. Wetl.Ecol. Manage. 20 (6) 491-502.

RIVERS-MOORE NA and GOODMAN PS (2011) River and wetland classifications for freshwater conservation planning in KwaZuluNatal, South Africa. Afr. J. Aquat. Sci. 35 (1) 61-72.

ROWNTREE KM and WADESON RA (1999) A hierarchical geomorphological model for the classification of selected South African rivers. WRC Report No. 497/1/99 1-360. Water Research Commission, Pretoria.

ROWNTREE KM, WADESON RA and O'KEEFE J (2000) The development of a geomorphological classification system for the longitudinal zonation of South African rivers. S. Afr. Geogr. J. 82 (3) 163-172. https://doi.org/10.1080/03736245.2000.9713710

SCHAEL DM, GAMA PT and MELLY BL (2015) Ephemeral wetlands of the Nelson Mandela Bay Metropolitan Area: Classification, biodiversity and management implications. (WRC) Report No. 2181/1/15. Water Research Commission, Pretoria.

SCHULZE RE (2007) South African Atlas of Climatology and Agrohydrology. WRC Report No. 1489/1/06. Water Research Commission, Pretoria.

SCHULZE RE, MAHARAJ M, LYNCH SD, HOWE BJ and MELVILTHOMSON B (1997) South African Atlas of Agrohydrology and Climatology. WRC Report No. TT82/96. ACRU Report No. 46. Water Research Commission, Pretoria.

SIEBEN EJJ, MTSHALI H and JANKS M (2014) National Wetland 
Vegetation Database: Classification and analysis of wetland vegetation types for conservation planning and monitoring. WRC Report No. 1980/1/14. Water Research Commission, Pretoria.

SNADDON K and DAY A (2009) Prioritisation of city wetlands. Report and shapefiles submitted to the City of Cape Town: Department of Environmental Resource Management. The Freshwater Consultancy Group (FCG), Cape Town.

SNADDON K, JOB N, DAY L, NEL J and SMITH-ADAO L (2008) C.A.P.E. fine-scale planning project: surface freshwater ecosystems. Methodology report. The Freshwater Consulting Group (FCG) and Council for Scientific and Industrial Research (CSIR), Cape Town.

SNADDON K, TURNER R, JOB N, OLLIS D and JONES L (2009) City wetlands map: Phase 5 - Ground-truthing and map update. Submitted by the Freshwater Consultancy Group to the City of Cape Town, Department of Environmental Resources Management. The Freshwater Consultancy Group (FCG), Cape Town.

SOIL SURVEY STAFF (1972-2010) Digital national soil profile database. Agricultural Research Council: Institute for Soil, Climate and Water (ARC:ISCW), Pretoria.

SAIAB (South African Institute for Aquatic Biodiversity) (2016) Specimen-records of preserved specimens and observations in the database of the National Collection of Fishes of South Africa, v. 1.2. Dataset/Occurrence. URL: http://ipt.saiab.ac.za/ resource? $r=$ saiab\&v=1.7. (Accessed 24 July 2017).

SANBI (South African National Biodiversity Institute) (2009) Further development of a proposed National Wetland Classification System for South Africa. SANBI, Pretoria, South Africa.

THIRION C (2016) The determination of flow and habitat requirements for selected riverine macoinvertebrates. $\mathrm{PhD}$ thesis, University of the North-West.

THOMPSON M (1996) A standard land-cover classification scheme for remote-sensing applications in South Africa. .S Afr. J. Sci. 92 34-42.

THOMPSON M, MARNEWECK G, BELL S, KOTZE D, MULLER J, COX D and CLARK R (2002) A Methodology Proposed for a South African National Wetland Inventory. Report to John Dini, Wetlands Conservation Programme, Department of
Environmental Affairs and Tourism. Council for Scientific and Industrial Research (CSIR), Pretoria, South Africa.

TURAK ET AL (2016) Essential Biodiversity Variables for measuring change in global freshwater biodiversity. Biol. Conserv. 213 (Part B) 272-279.

UCT (University of Cape Town) (2010) Coordinated Waterbirds Counts (CWAC) data compiled by the Animal Demography Unit of UCT. University of Cape Town, Cape Town.

VAN DEN BERG EC, PLARRE C, VAN DEN BERG HM and THOMPSON MW (2008) The South African National Land Cover 2000. Report No. GW/A/2008/86. Agricultural Research Council: Institute for Soil, Climate and Water (ARC:ISCW), Pretoria.

VAN DEVENTER H, CHO MA and MUTANGA O (2017) Improving the classification of six evergreen subtropical tree species with multi-season data from leaf spectra simulated to WorldView-2 and RapidEye. Int. J. Remote Sens. 38 (17) 4804-4830. https://doi.org/10 $.1080 / 01431161.2017 .1320445$

VAN DEVENTER H, NEL J, MAHERRY A and MBONA N (2014) Using the landform tool to calculate landforms for hydrogeomorphic wetland classification at a country-wide scale. S. Afr. Geogr. J. 98 (1) 138-153. https://doi.org/10.1080/03736245.2014.977812

VAN DEVENTER H, NEL JL, MBONA N, JOB N, EWART-SMITH J and MAHERRY A (2016) Desktop classification of inland wetlands for systematic conservation planning in data-scarce countries: mapping wetland ecosystem types, disturbance indices and threatened species associations at country-wide scale. Aquat. Conserv.: Mar. Freshwater Ecosyst. 26 57-75. https://doi.org/10.1002/aqc.2605

WANG L, SOUSA WP, GONG P and BIGING GS (2004) Comparison of IKONOS and QuickBird images for mapping mangrove species on the Caribbean coast of Panama. Remote Sens. Environ. 91 (3-4) 432-440. https://doi.org/10.1016/j.rse.2004.04.005

WEEPENER HL, VAN DEN BERG HM, METZ $M$ and

HAMANDAWANA H (2012) The development of a hydrologically improved Digital Elevation Model and derived products for South Africa based on the SRTM DEM. WRC Report No. 1908/1/11. Water Research Commission, Pretoria. 


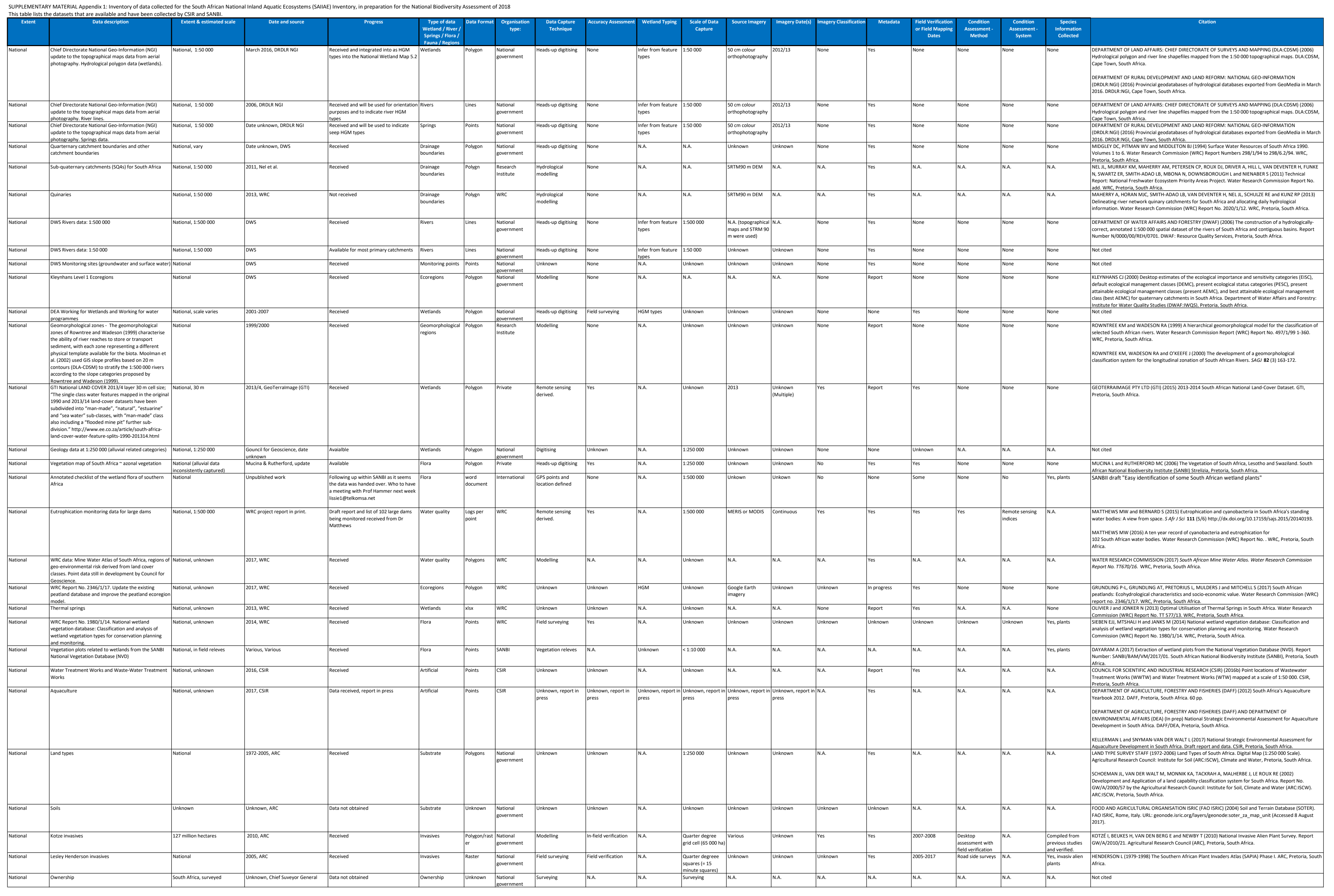




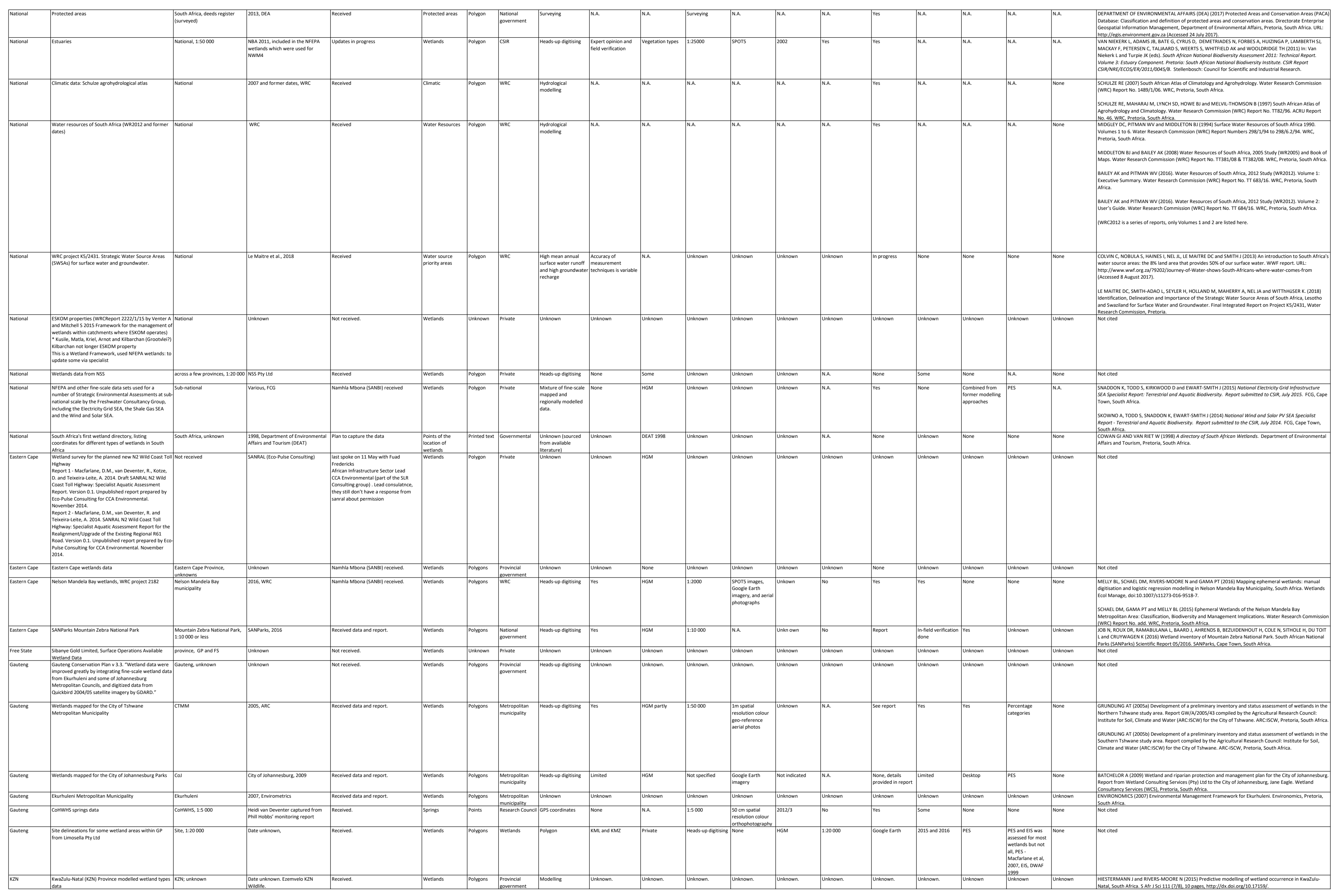




\begin{tabular}{|c|c|c|c|c|c|c|c|c|c|c|c|c|c|c|c|c|c|c|c|c|}
\hline 2N & 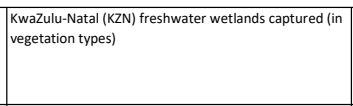 & Fan, natrown & 2000 ERENW & Fecerved & Wetanons & Poryens & 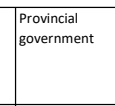 & 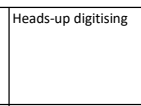 & Junkomm & Unthowem & Juntrown: & Jontromen: & Juntromenn & Junkown & Jonkown. & Unknown. & Jontrown & Unkown & Juknown & 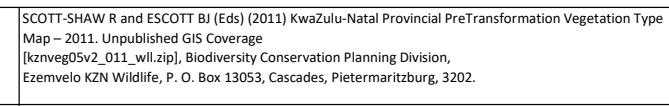 \\
\hline N & 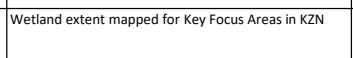 & 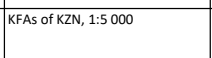 & anom, 2017 & Recenved & Wetands & Polvens & 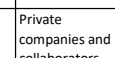 & 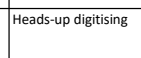 & timitied & None & 1.5000 & 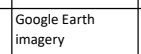 & Unanown: & & & Unkown & Inprogeress & In progeress & None & 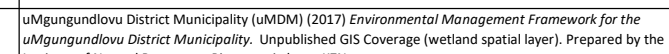 \\
\hline 20 & 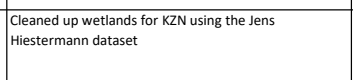 & 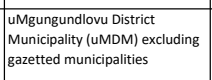 & unom, 2017 & Recerived & Wetanants & Pongerons & 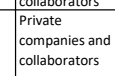 & data & None & None & Na & an & 筑 & & & & None & None & None & 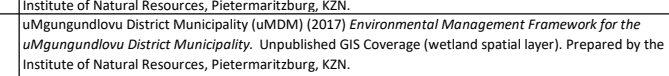 \\
\hline 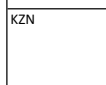 & 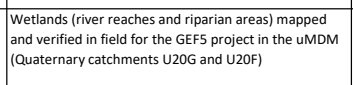 & 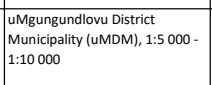 & 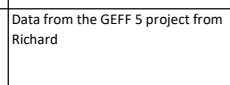 & Received & 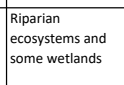 & Ponveros & 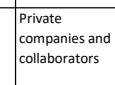 & 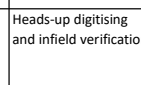 & None & & 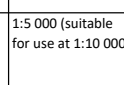 & 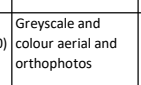 & $1990-2015$ & NA. & & & Unkrown & Unkrown & None & 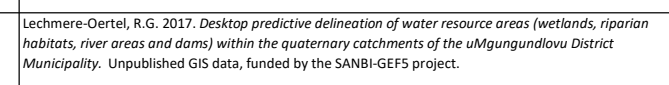 \\
\hline KaN & Riparain datat from Grovondrath & 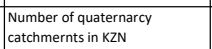 & Groundtruth 2014 & Jotat on ortecenved & $\begin{array}{l}\text { Riparan } \\
\text { earosstems }\end{array}$ & Reverines & 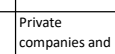 & Unanown & Unknown & 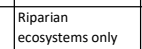 & 2150000 & Unknown & Unarowenn & NA. & 105 & Unkown & Mocoleder & PESEES & None & 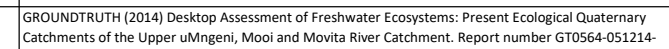 \\
\hline 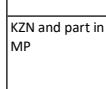 & Weltands datat for WWF F reass of i interest & 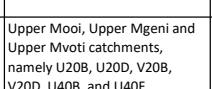 & 2015, Groundruth & Fececived & 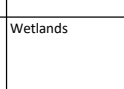 & Poryens & 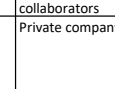 & Heasdsup dightising & None & None & 1.50000 & 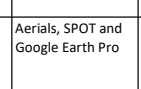 & Unkrown & NA. & Nonee & Unknown & Masolened & Kotate 2015 & Nonee & 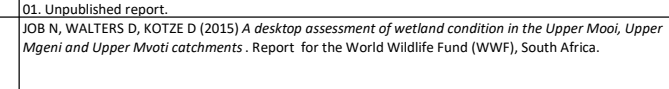 \\
\hline KZN & 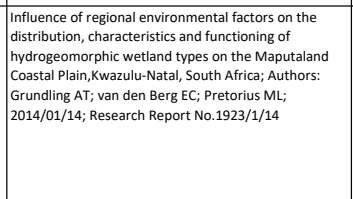 & & Aatrea Grundling phi & Fecesved. & Wetinats & 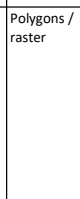 & WRC & Unmomome & Unkrown. & Unknown. & Untrownen: & Juknown. & Uomeromenn & 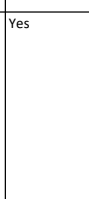 & None. & Unkown. & Untrown & Unkrown & Unknown & 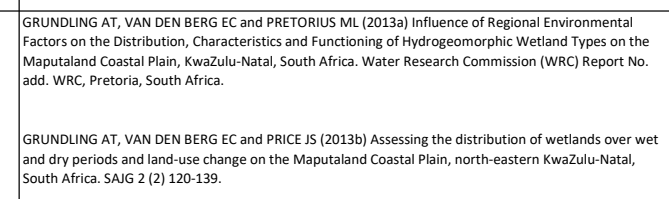 \\
\hline$\frac{K^{K N N}}{k N}$ & 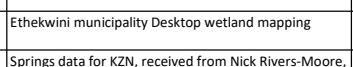 & Doubran intown & Warcenoles & 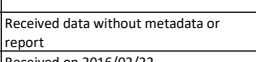 & 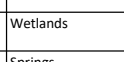 & Poryons & 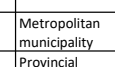 & unhourn & Unhomenn & Juknown & Uninown & onthourn & Unthown & Unknown & None. & Juknown & Untrowown & Unknown & Unklown & Nocticed \\
\hline 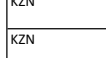 & 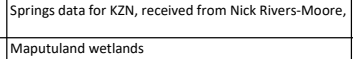 & 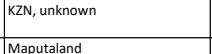 & Nockiversisoore & 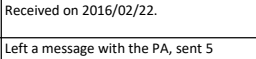 & Springs & Points & 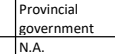 & 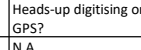 & N.A. & $\int_{\text {NA. }}^{\text {Nat }}$ & na. & Nas. & NAA & NN.A. & N.A. & N.A. & Nas. & NN.A. & N.A. & $f^{\text {Not ctited }}$ \\
\hline (17) & 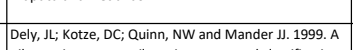 & 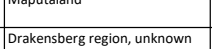 & 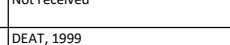 & 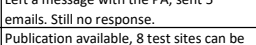 & Wetanans & Na. & & N.A. & N... & Na. & Na. & $\int^{\mathrm{NA}}$ & Na & 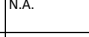 & 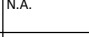 & 垔 & 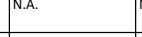 & da. & 筑 & Noctitied \\
\hline & 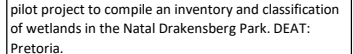 & & & 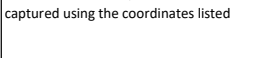 & 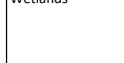 & 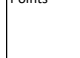 & 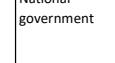 & (a) & 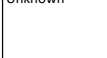 & troes & The & 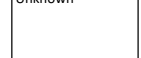 & 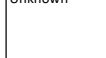 & a & (3) & (5) & 年 & 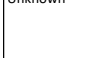 & 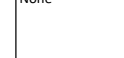 & 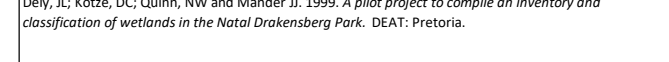 \\
\hline Impopo & 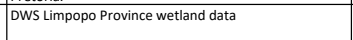 & Provonne & 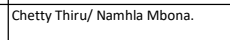 & 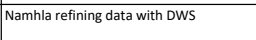 & Wetranast & Porven & 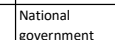 & Desticom mapong & Nonere & None & 12020000 & Sports ond & 2014 & & & Partalin & None & Noner & Tone & Noctited \\
\hline timpooso & 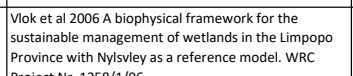 & Norsivey & 2006 , Whe project & Jobained tepont & fanna & Points & wisec & & & NA. & Unmenown: & Junkrown. & Unmenown & Unknown & Unnrown & Unkown & Unknown & Unkrown & Unkrown & 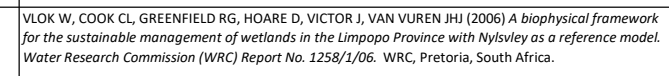 \\
\hline Inmpopo & 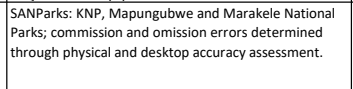 & Regional, 1.500000 & 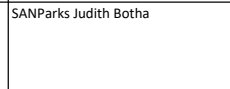 & 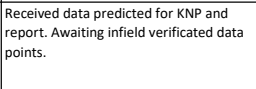 & Wetanass & & 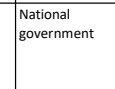 & NA. & Yes & Yes & lansist & landsat & 2011 & Yes & Yes & Yes & Uninowern & Uninown & None & 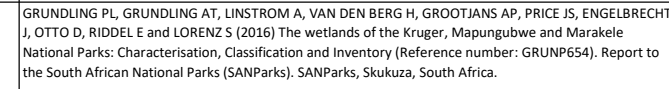 \\
\hline Limpoono & 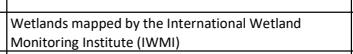 & unmpoon & WWM & Fececented. & Wetands & Polyens & Irementional & 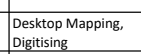 & None & some & Unknown & unkrown & Unmenown & the & None & Yes & None & None & None & Noctited \\
\hline unalare & 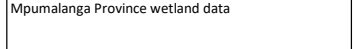 & Highveld gasslands & Notreceved & 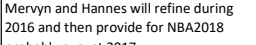 & Wetitans & Porgens & $\begin{array}{l}\text { Provicial } \\
\text { covernment }\end{array}$ & Headsup digtitsing & Veifty & None & Unthown & Jonowown & Uonowown & Unknown & Unhrown & unkown & Juncowoun & Unkrown & Jonkown & Not cited \\
\hline Cunarabega & Mpumalanga Highveld WE F Project data & Moumananga Hithered & Mbone etal, 2015 & 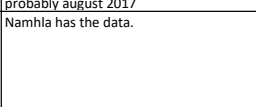 & Welatars & Polyerens & National & Headsulup dibtsting & None & нсм & 1:10000 & 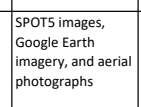 & 201222014 & No & Yres & res & Yes & Modeled & 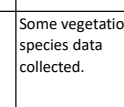 & 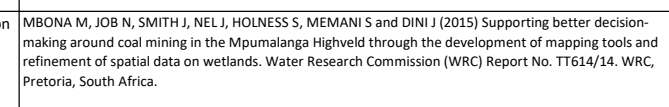 \\
\hline Movenabaras & Aniton linstromin'stata & 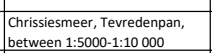 & 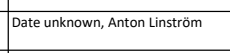 & Done & Welatanst & Ponverens & Pervate & 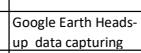 & None & None & 2.5000 & 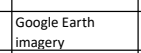 & Mutitiple & Na. & Nonee. & 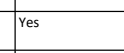 & None & Na. & None & Notctited \\
\hline Norteren cope & 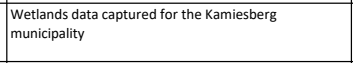 & $\begin{array}{l}\text { Tamiesberer Muncicipalty, } 1: 10 \\
\text { coo }\end{array}$ & $2009,100 \mathrm{MM}$ & Fececived & Wetands & Pongerens & קrivate & 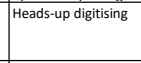 & Liminied & 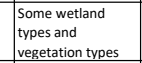 & 1:10000 & 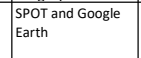 & Mutitiple & Na. & None. & Ulinited & None & Na. & None & 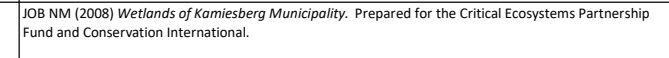 \\
\hline orterenc cope & 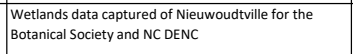 & 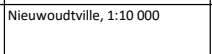 & $2009,00 \mathrm{BM}$ & Recesved & Welatans & Polyens & Private & Headsupidititsing & Limined & 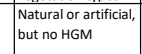 & ]$_{10000}$ & 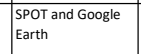 & moutiple & NA. & None. & Irited & None & NA. & None & 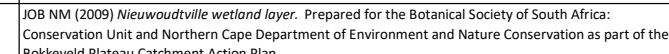 \\
\hline riten crove & 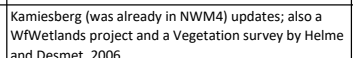 & Muncicianty, & Helme and Desmet, 2006 & Recenved & Vegetation & Poryens & rivite & 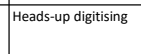 & Notoro wet & 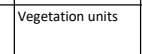 & $\left.\right|^{1.5000}$ & |ronos & 2003 & va. & es & 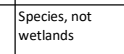 & Na. & 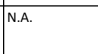 & tora and & 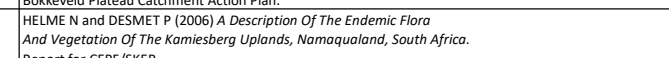 \\
\hline riten crave & 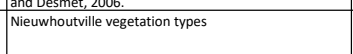 & 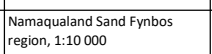 & 2009 , osemetetat, & Fececened & vegeztationt & Ponverens & Private & 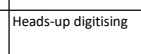 & Unkinown & vegetation tree & 1.10000 & ssoors & Unintown & Na. & None. & 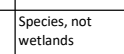 & NA. & Na. & Frotanant & 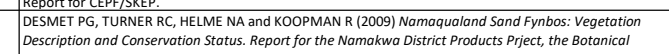 \\
\hline Fortitern cope & 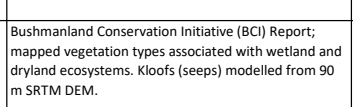 & Bcaratea, 12505000 & 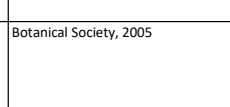 & Recerived & 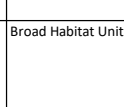 & Poryerars & 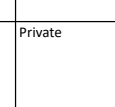 & 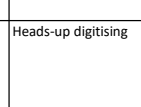 & Unkrown: & 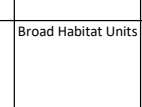 & $5: 2.25000$ & 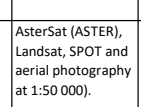 & Uninown & Na. & Yves & Juknown & Na. & Na. & 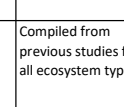 & 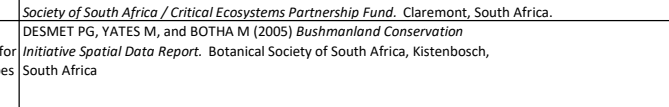 \\
\hline Nocteren crope & 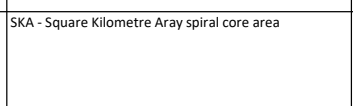 & Regional, 1.50 0000 or less & DEA, 2016 & 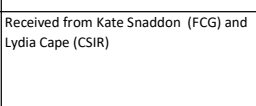 & Welatars & Pongen & EaA & Headsulud digtitising & For trecess reas & HGM & $2120000-1220000$ & 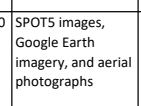 & 2011 & Wone & 然 & 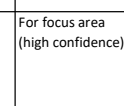 & 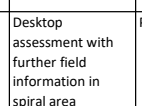 & ES & unkown & 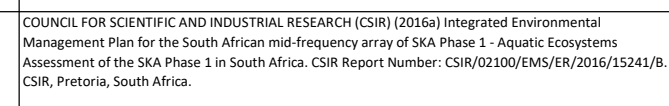 \\
\hline rithen crae & 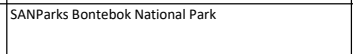 & Boneteon National Park, trod & 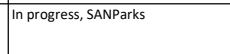 & Recesved & Wetelans & Poryens & ational & Unmomeme & Unthown. & нсм & Untrownen. & Unkrown. & Unmomown. & Unknowown. & Unkrown & Unkrown. & 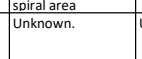 & Unkrown & Unkrown. & 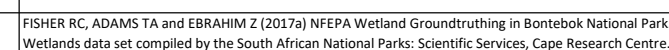 \\
\hline then cope & Wetalands datat fom Andete crobler & Sulub-istritit & Inknown, Antre Grobler & Rececived & Wetands & Ponverons & riviate & 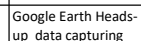 & None & Hom & 0000.5 & Fogel eath & Hhowewn & one & ore & & None & (t) & None & 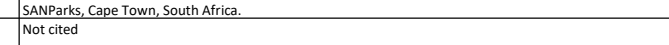 \\
\hline otritwest & 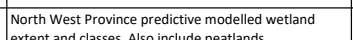 & 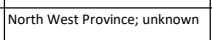 & 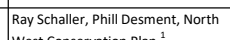 & 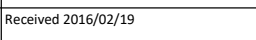 & Wetatans & Unlomown. & Frovicial & 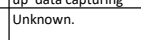 & Unknown. & tigm & Uninown: & 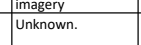 & Unlomown: & Wuncown: & Unhrowewn & Unkown. & Unkrown & Unkrown & Unknown & Notctited \\
\hline teren Cape & 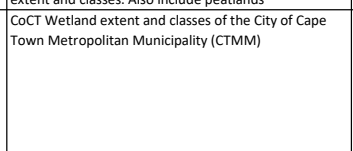 & $\operatorname{crmMM,1:10000}$ & 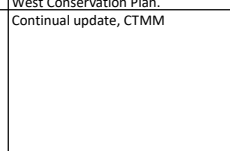 & Received & Wetands & Pongerens & 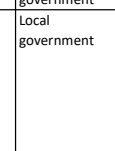 & 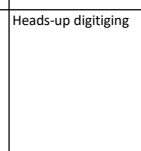 & Yes & HGM & 1:100000 & tspectifed & Not spectifed & $y_{1}$ & & Unkown. & Unknown & $f^{\prime}$ & Unknown & 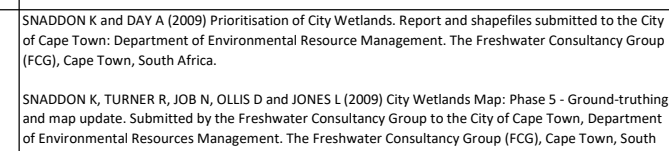 \\
\hline Vesterem Cape & 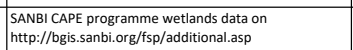 & 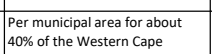 & Variolus,SNAEI & Received & Welanass & Pongens & Care tunding & Headsupu difitibing & None & HсM & 1:10000 & erthos and s sor & Not spectified & A. & 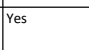 & Unkown & Destitop moc & PES & None & 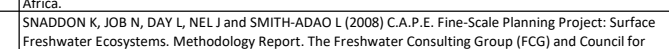 \\
\hline esten cope & $\int_{\text {Area }}$ & $\begin{array}{l}\text { Protonce } \\
\text { Recured }\end{array}$ & 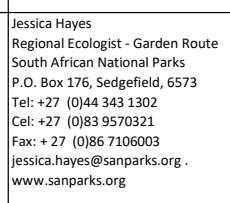 & 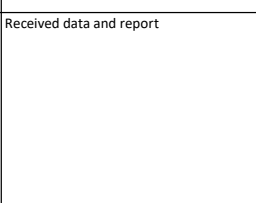 & Wetinans & Uninown & $\begin{array}{l}\text { Notional } \\
\text { covernmen }\end{array}$ & Unmown & Unkrown & Unikowew & Unknown & Juknown & Unkrown & Unkrown & Unnkown & Unkown & Unknown & Unknown & unkenown & 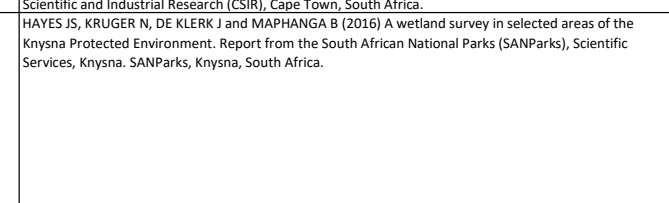 \\
\hline term cape & Alanna Rebelol Pho thesis work & 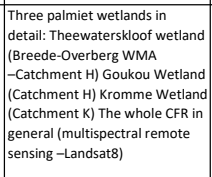 & 2017, Alanás ShD. & 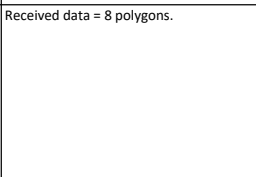 & Wetanns & & rivers & poiditsisng & verriti & & 1.5000 & 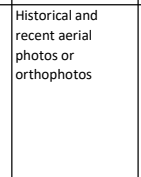 & 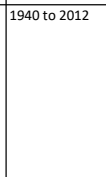 & & & & & & 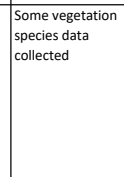 & 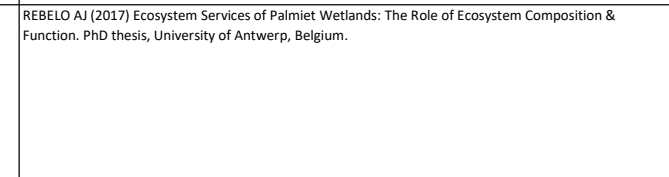 \\
\hline 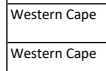 & 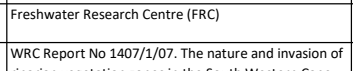 & 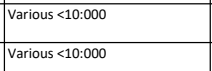 & $\begin{array}{l}\text { Sine } 19805 \\
\text { sine } 19805\end{array}$ & 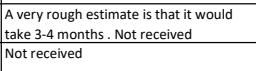 & 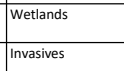 & Unthown & $\begin{array}{l}\text { piniste } \\
\text { wrec }\end{array}$ & 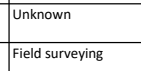 & 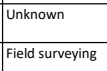 & Wonkown & 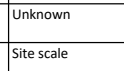 & unkrown & Unomown & Unknown & Unhrown & Unkown & Junkown & $\begin{array}{l}\text { Unknown } \\
\text { Unhrowown }\end{array}$ & $\begin{array}{l}\text { Uunkown } \\
\text { Yess riparian }\end{array}$ & Nisocteded \\
\hline & & & & & & & & & & & & & & & & & & & & \\
\hline
\end{tabular}




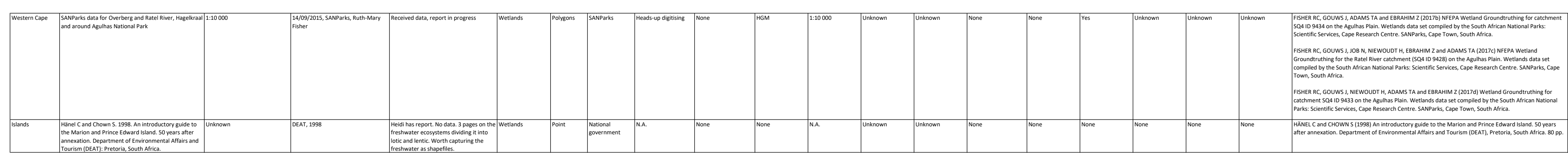

